\title{
БАГАТОКРИТЕРІАЛЬНА (ВЕКТОРНА) ОПТИМІЗАЦІЯ ПОРТФЕЛЯ ВАЛЮТ ПРИ НЕСТОХАСТИЧНО НЕВИЗНАЧЕНОМУ ЗОВНІШНЬОМУ ЕКОНОМІЧНОМУ СЕРЕДОВИЩІ
}

\author{
С.В. Гадецька ${ }^{1}$, В.Ю. Дубницький ${ }^{2}$ Ю.І. Кушнерук ${ }^{3}$, О.І. Ходирєв ${ }^{2}$, І.В. Шкодіна ${ }^{2}$ \\ ${ }^{1}$ Харківський наиіональний автомобільно-дорожній університет, Харків \\ ${ }^{2}$ Навчально-науковій інститут "Каразінський банківський інститут" \\ Харківського начіонального університету ім. В.Н. Каразіна, Харків \\ ${ }^{3}$ Харківський національний університет Повітряних Сил ім. І. Кожедуба, Харків
}

На основі аналізу літератури встановлено, щзо невизначеності різної природи, які властиві операціям по конвертації валют з урахуванням чинника часу, вимагають використовувати хеджування валютних ризиків. Встановлено, щзо серед моделей хеджування ризиків одна з найбільш поширених моделей - модель Марковіца. В роботі розглянуто ї̈ використання за результатами можливих значень курсу валют у майбутньому. Для розв'язання задачі у майбутньому часі запропоновано використання інтервальних чисел, представлених в системі ЦЕНТР-РАДІУС. В роботі запропоновано наступні методики: визначення основних статистичних характеристик зміни курсів валют, включених до складу портфелю; визначення статистичного зв'язку між окремими валютами, включеними до складу портфелю; визначення статистичних властивостей часового ряду даних про зміну курсу валют. Сформульована задачу Марковіца як задачу багатокритеріальної (векторної) оптимізачії портфеля валют при нестохастично невизначеному зовнішньому економічному середовищі. Розв'язання такої задачі (структура портфелю валют) одночасно дає можливість максимізувати прибуток $і$ одночасно мінімізувати ризик операцій, пов'язаних з конверсією валют. Для розв'язання задачі використано згортку критеріїв, яка забезпечує зменшення відносних значень изільових функиій від їх оптимальних значень рівномірно.

Ключові слова: валютні операції, конвертація валюти, хеджування ризиків, задача Марковіца, векторна оптимізація, інтервальні обчислення.

\section{Вступ}

Постановка проблеми. В умовах пандемії COVID-19 уряди країн та центробанки втручаються в грошово-кредитну та фіскальну політику, в результаті чого посилюється волатильність валютних ринків. Зміна валютних курсів залежить від багатьох інституційних факторів (економічних, політичних, соціальних, екологічних та ін.) та позначається на всіх економічних процесах, як на міжнародному, так і національному рівні. У результаті девальвації національної валюти відбувається перерозподіл світового багатства, при якому країни та суб'єкти господарювання втрачають значні активи. В цих умовах питання хеджування валютних ризиків стають вкрай актуальними для всіх суб'єктів господарювання.

Проблемам дослідження валютних курсів та можливостей їх змін під дією різних економічних та неекономічних чинників присвячено роботи багатьох вітчизняних та зарубіжних вчених-економістів. Основним нормативним документом, у якому викладено основні вимоги до міжнародних валютних розрахунків, є робота [1, С. 125, п. 5-106]. У роботах [2-5] розглянуто методи валютного регулювання та базові аспекти впливу держави в особі центрального банку країни на зовнішньоекономічні відносини через відповідну валютну політику. Також вивчено основні механізми організації валютного регулювання в ринкових умовах господарювання і в перехідний період, а також висвітлено ряд практичних засад реалізації валютної політики, пов'язаних із управлінням обмінним курсом, платіжним балансом, золотовалютними резервами і застосуванням валютних обмежень. Розглянуто теоретичні основи, механізми формування і функціонування міжнародних фінансів у світовій економіці; засоби їхнього залучення і ефективності використання у національних економіках. Детально вивчено базові аспекти впливу держави в особі центрального банку країни на зовнішньоекономічні відносини через відповідну валютну політику. Розглядаються основні механізми організації валютного регулювання в ринкових умовах господарювання і в перехідний період, а також висвітлюється ряд практичних засад реалізації валютної політики, пов'язаних з управлінням обмінним курсом, платіжним балансом, золотовалютними резервами і застосуванням валютних обмежень. Також розглянуто питання щодо ризиків валютних операцій та міжнародних розрахунків. На думку авторів даного повідомлення, слід звернути увагу на одну важливу обставину. У назві вищеназваних ро- 
біт присутні слова “валютні операції, міжнародні розрахунки”. Більше того, в навчальній програмі дисципліни "Міжнародні розрахунки і валютні операції”, прийнятій в одному з вишів України, сказано, що дисципліна "Міжнародні розрахунки і валютні операціï” поглиблює та конкретизує знання студентів, здобуті в процесі вивчення дисциплін "Гроші та кредит”, “Фінанси підприємств”, “Банківські операції”, “Міжнародна економіка” з акцентом на міжнародні розрахункові та валютні операції і тісно пов'язана $з$ темами навчальних дисциплін “Фінансовий менеджмент у банку” та “Платіжні системи”. У переліку цих дисциплін відсутня дисципліна “Фінансова математика”, яка є теоретичним підгрунтям для виконання будь-яких фінансових обчислень, у тому числі й тих, які необхідні при проведенні валютних операцій. Слід зазначити, що в найбільш поширених підручниках із фінансової математики, таких як, наприклад [6-10], відсутні розділи, пов'язані з аналізом валютних обчислень. Цю прогалину заповнюють роботи [11-13].

Аналіз літератури. В роботах $[11 ; 13]$ детально розглянуто задачі, які виникають при виконанні валютних розрахунків, методи їх розв'язання та економічний зміст отриманих результатів. Введемо наступні скорочення: КВ - конвертована валюта, НВ - національна валюта. Будемо розглядати наступні операції:

1. Розміщення депозиту в іноземній валюті без конверсії: $\mathrm{KB} \rightarrow \mathrm{KB}$.

2. Розміщення депозиту в іноземній валюті 3 подвійною конверсією: $\mathrm{KB} \rightarrow \mathrm{HB} \rightarrow \mathrm{HB} \rightarrow \mathrm{KB}$.

3. Розміщення депозиту в національній валюті без конверсії: HB $\rightarrow$ HB.

4. Розміщення депозиту в національній валюті 3 подвійною конверсією: $\mathrm{HB} \rightarrow \mathrm{KB} \rightarrow \mathrm{KB} \rightarrow \mathrm{HB}$.

У подальшому будемо використовувати наступні умовні позначення:

$P_{v}$ - сума депозиту у КВ;

$P_{n}-$ сума депозиту у НВ;

$S_{v}$ - нарощена сума у КВ;

$S_{n}$ - нарощена сума у НВ;

$K_{0}$ - курс обміну на початку операції (курс КВ по відношенню до НВ, визначений в одиницях НВ);

$K_{1}-$ курс обміну в кінці операції;

$n$ - термін депозиту (роки);

$i$ - річна ставка нарощення для депозитів у НВ;

$j$ - річна ставка нарощення для депозитів у КВ.

Розглянемо варіант розміщення депозиту по схемі: КВ $\rightarrow$ КВ. Кінцева сума валютного депозиту, визначена по схемі простих відсотків, може бути визначена за виразом:

$$
S_{v}=P_{v}(1+n j) .
$$

Розглянемо варіант розміщення депозиту по схемі: $\mathrm{KB} \rightarrow \mathrm{HB} \rightarrow \mathrm{HB} \rightarrow \mathrm{KB}$. Кінцевий розмір валютного депозиту у КВ, з урахуванням зростання вкла- ду по схемі простих відсотків, може бути визначений за виразом:

$$
S_{v}=P_{v} K_{0}(1+n j) \frac{1}{K_{1}} .
$$

Розглянемо варіант розміщення депозиту по схемі: НВ $\rightarrow$ НВ. Кінцева сума депозиту в національній валюті, обчислена по схемі простих відсотків, може бути визначена за виразом:

$$
S_{n}^{(1)}=P_{n}(1+n i) .
$$

Розглянемо варіант розміщення депозиту по схемі: $\mathrm{HB} \rightarrow \mathrm{KB} \rightarrow \mathrm{KB} \rightarrow \mathrm{HB}$. Нарощену суму в національній валюті, величину $S_{n}$, визначають згідно 3 формулою:

$$
S_{n}^{(2)}=\frac{P_{n}}{K_{0}}(1+n j) K_{1} .
$$

Нормативну методику визначення курсів валют викладено в роботі [14]. У співвідношення (1)-(4) входять величини $K_{0}$ i $K_{1}$, тобто курси валют на початку і в кінці операції. Якщо початок фінансової операції співпадає з часом ухвалення рішення про іiі проведення, то значення величини $K_{0}$ відомо точно, якщо операція планується в майбутньому, то необхідно отримати наближену оцінку величини $K_{0}$. У будь-якому випадку оцінка величини $K_{1}$ може бути тільки наближеною. В рамках даної роботи величину $K_{0}$ будемо вважати відомою точно. Якщо майбутню невизначеність розглядають як стохастичну, то для прогнозування валютного курсу використовують статистичні методи [15]. Якщо майбутню невизначеність розглядають як нестохастичну, то для прогнозування валютного курсу використовують методи нечіткої логіки [12]. У цьому випадку для визначення результатів фінансової операції використовують методи інтервального аналізу [16]. Невизначеності різної природи, які властиві операціям по конвертації валюти з урахуванням чинника часу, вимагають використання спеціальних методів для зменшення ризиків, які виникають внаслідок непередбаченої зміни валютних курсів. Ці методи отримали назву “Хеджування валютних ризиків”. Фінансовий аналіз таких методів розглянуто в роботі [17]. Обчислювальні алгоритми, що реалізують ці методи, розглянуто в роботі [18].

Серед моделей хеджування ризиків одна 3 найбільш поширених моделей - модель Марковіца. Їі теоретичне обгрунтування наведено в роботі [19]. Варіанти розв'язання цієї задачі розглянуто в роботах [19; 21]. Основні припущення, прийняті при цьому, наступні:

1. Визначена кількість активів $z$ (портфель активів).

2. Для кожного $31,2, \ldots, u, \ldots, z$ видів активів відома його прибутковість $r_{1}, r_{2}, \ldots, r_{u}, \ldots, r_{z}$.

3. Прибутковість кожного 3 активів прийма- 
ють випадковою нормально розподіленою величиною $з$ математичним сподіванням $m_{u}$ і дисперсією $\sigma_{u}^{2}$, середнім квадратичним відхиленням $\sigma$.

Мета задачі - визначити структуру портфелю, тобто питому вагу кожного 3 активів $x_{u} 0 \leq x_{u} \leq 1$. У цьому випадку класичними прийнято вважати три варіанти постановки задачі.

Задача 1. Максимізувати прибутковість портфелю активів $V$ при обмеженні загального ризику портфелю $W$.

У цьому випадку умови задачі мають вигляд

$$
\begin{gathered}
V=\sum_{u=1}^{z} x_{u} m_{u} \rightarrow \max ; \\
\sum_{u=1}^{z} \sum_{q=1}^{z} \operatorname{COV}\left(r_{u}, r_{q}\right) x_{u} x_{q} \leq W_{0} .
\end{gathered}
$$

Така постановка задачі вимагає пошуку структури портфелю, яка максимізує прибутковість портфеля, визначену співвідношенням (5), при обмеженні на величину ризику, який визначається співвідношенням (6) і залежить від дисперсії кожного 3 активів та їх взаємної статистичної залежності.

Задача 2. Необхідно мінімізувати ризик портфеля при отриманні деякого гарантованого прибутку. В цьому випадку умови задачі мають наступний вигляд:

$$
\begin{gathered}
W=\sum_{u=1}^{z} \sum_{q=1}^{z} \operatorname{COV}\left(r_{u}, r_{q}\right) x_{u} x_{q} \rightarrow \min ; \\
\sum_{u=1}^{z} x_{u} m_{u} \geq V_{0} . \\
\sum_{u=1}^{z} x_{u}=1 ; x_{u} \geq 0 ; u=1, \ldots, z .
\end{gathered}
$$

Задача 3. Необхідно сформувати структуру портфеля, яка максимізує прибуток і одночасно мінімізує ризик:

$$
\begin{gathered}
V=\sum_{u=1}^{z} x_{u} m_{u} \rightarrow \max \\
W=\sum_{u=1}^{z} \sum_{q=1}^{z} \operatorname{COV}\left(r_{u}, r_{q}\right) x_{u} x_{q} \rightarrow \min . \\
\sum_{u=1}^{z} x_{u}=1 ; x_{u} \geq 0 ; u=1, \ldots, z .
\end{gathered}
$$

Використання цих задач для формування портфеля валют має важливу особливість. Виходячи зі співвідношень (1)-(4) для їх розв'язання необхідно знання курсу валют через $n$ одиниць часу. Необхідність прогнозування курсу валют багато в чому ускладнюється наявністю обставин, що мають нестохастичну невизначеність. Це можуть бути різного роду політичні обставини, катастрофи природного і техногенного характеру, прогнозування яких статистичними методами неможливе. Для вирішення задачі Марковіца з урахуванням вказаних обставин в роботах [22-23] запропоновано використовувати нечіткі числа. Для цього необхідне знання їх функцій приналежності, що само по собі може бути предметом самостійного дослідження. На думку авторів даної роботи більш простішим методом розв'язання задачі Марковіца в умовах нестохастичної невизначеності може бути використання інтервальних чисел, визначених в системі ЦЕНТРРАДІУС. Правила операцій $з$ такими числами викладено в роботі [24], застосування цих чисел для валютних розрахунків описано в роботі [16].

Мета дослідження. Розробка методу векторної оптимізації структури валютного портфелю в умовах нестохастичної невизначеності зовнішнього економічного середовища.

Для вирішення цього завдання необхідно розв'язати проміжні задачі:

- визначення основних статистичних характеристик зміни курсів валют, включених до складу портфелю;

- визначення статистичного зв'язку між окремими валютами, включеними до складу портфелю;

- визначення статистичних властивостей часового ряду даних про зміну курсу валют;

- розв'язання задачі векторної оптимізації 3 використанням інтервальних чисел, представлених в системі ЦЕНТР-РАДІУС.

\section{Виклад основного матеріалу}

У зв'язку з тим, що мета дослідження - пропозиції до методики формування портфелю валютних депозитів, то, на думку авторів даної роботи, це дозволяє використовувати дані про курси валют на довільно вибрані, але зіставні дати. У нашому випадку використано дані за 2018, 2019 рр., оскільки в цей період у світовій економіці не відбувалося значущих змін або потрясінь.

Визначення основних статистичних характеристик валют, включених до складу валютного портфеля. Курси валют, використаних в роботі станом на 2019 р., запозичені з роботи [33] і приведені в табл. 1.

Таблиця 1

Середні щомісячні курси валют

\begin{tabular}{|c|c|c|l|c|c|c|c|}
\hline \multirow{2}{*}{ Назва валюти } & \multirow{2}{*}{ Код } & \multicolumn{6}{|c|}{2019 рік } \\
\cline { 3 - 8 } & валюти & січень & лютий & березень & квітень & травень & червень \\
\hline 100 Австралійських доларів & 1 & 1986,26 & 1941,95 & 1903,17 & 1906,56 & 1833,26 & 1839,50 \\
\hline
\end{tabular}




\begin{tabular}{|c|c|c|c|c|c|c|c|}
\hline & & & & & & \multicolumn{2}{|c|}{ Закінчення табл. 1} \\
\hline 100 Англійських фунтів стерлінгів & 2 & 3580,73 & 3529,71 & 3542,34 & 3494,70 & 3391,75 & 3358,68 \\
\hline 10 Білоруських рублів & 3 & 129,17 & 126,06 & 126,31 & 126,73 & 125,92 & 128,04 \\
\hline 100 Датських крон & 4 & 426,17 & 413,35 & 407,43 & 403,40 & 395,11 & 400,29 \\
\hline 100 Доларів США & 5 & 2787,92 & 2716,07 & 2686,35 & 2681,15 & 2637,88 & 2650,01 \\
\hline $100 \epsilon_{\text {вро }}$ & 6 & 3181,75 & 3084,84 & 3040,44 & 3011,46 & 2950,37 & 2989,08 \\
\hline 100 Казахстанських тенге & 7 & 7,37 & 7,20 & 7,11 & 7,07 & 6,94 & 6,93 \\
\hline 100 Канадських доларів & 8 & 2087,79 & 2056,14 & 2012,89 & 2003,05 & 1959,99 & 1991,04 \\
\hline 100 Молдовських леїв & 9 & 162,57 & 158,69 & 156,31 & 151,70 & 146,92 & 145,83 \\
\hline 100 Норвезьких крон & 10 & 324,99 & 316,79 & 312,87 & 313,06 & 302,08 & 306,72 \\
\hline 100 Польських злотих & 11 & 741,11 & 715,02 & 707,53 & 702,53 & 686,89 & 700,57 \\
\hline 10 Російських рублів & 12 & 4,14 & 4,13 & 4,12 & 4,15 & 4,07 & 4,13 \\
\hline $100 \mathrm{CПЗ}$ & 13 & 3883,98 & 3780,63 & 3740,01 & 3719,45 & 3645,09 & 3669,53 \\
\hline 100 Сінгапурських доларів & 14 & 2052,69 & 2006,91 & 1984,36 & 1976,86 & 1925,40 & 1942,90 \\
\hline 100 Турецьких лір & 15 & 518,29 & 515,31 & 491,60 & 465,67 & 435,93 & 455,73 \\
\hline 1000 Угорських форинтів & 16 & 99,36 & 97,04 & 96,28 & 93,82 & 90,84 & 92,62 \\
\hline 100 Чеських крон & 17 & 124,02 & 119,85 & 118,48 & 117,24 & 114,57 & 116,62 \\
\hline 100 Шведських крон & 18 & 309,82 & 294,09 & 289,66 & 287,45 & 274,93 & 281,20 \\
\hline 100 Швейцарських франків & 19 & 2820,24 & 2712,48 & 2687,03 & 2662,04 & 2606,65 & 2675,52 \\
\hline 100 Юанів женьміньбі (Китай) & 20 & 409,85 & 403,10 & 400,32 & 399,11 & 385,47 & 384,05 \\
\hline 1000 Японських єн & 21 & 255,90 & 246,51 & 241,64 & 240,21 & 239,40 & 244,92 \\
\hline \multirow{2}{*}{ Назва валюти } & Код & \multicolumn{6}{|c|}{2019} \\
\hline & валюти & липень & серпень & вересень & жовтень & листопад & грудень \\
\hline 100 Австралійських доларів & 1 & 1800,88 & 1712,31 & 1686,28 & 1683,62 & 1666,50 & 1622,99 \\
\hline 100 Англійських фунтів стерлінгів & 2 & 3220,66 & 3067,21 & 3059,01 & 3121,98 & 3141,18 & 3089,39 \\
\hline 10 Білоруських рублів & 3 & 126,45 & 122,99 & 119,19 & 120,58 & 118,56 & 112,04 \\
\hline 100 Датських крон & 4 & 387,30 & 376,46 & 365,50 & 366,86 & 360,79 & 350,76 \\
\hline 100 Доларів США & 5 & 2575,14 & 2524,70 & 2476,97 & 2480,82 & 2436,75 & 2360,94 \\
\hline 100 Євро & 6 & 2891,35 & 2808,61 & 2727,66 & 2740,11 & 2695,84 & 2620,69 \\
\hline 100 Казахстанських тенге & 7 & 6,71 & 6,53 & 6,40 & 6,37 & 6,28 & 6,15 \\
\hline 100 Канадських доларів & 8 & 1967,03 & 1902,66 & 1870,20 & 1878,61 & 1841,75 & 1791,41 \\
\hline 100 Молдовських леїв & 9 & 144,97 & 142,33 & 139,48 & 141,36 & 139,47 & 136,08 \\
\hline 100 Норвезьких крон & 10 & 299,70 & 282,03 & 274,87 & 271,26 & 266,35 & 261,04 \\
\hline 100 Польських злотих & 11 & 679,21 & 646,59 & 626,66 & 636,30 & 629,52 & 613,00 \\
\hline 10 Російських рублів & 12 & 4,08 & 3,86 & 3,81 & 3,85 & 3,81 & 3,75 \\
\hline $100 \mathrm{C} \Pi 3$ & 13 & 3559,53 & 3465,86 & 3390,03 & 3402,13 & 3351,56 & 3254,33 \\
\hline 100 Сінгапурських доларів & 14 & 1893,45 & 1824,45 & 1794,74 & 1808,36 & 1790,12 & 1738,60 \\
\hline 100 Турецьких лір & 15 & 454,26 & 448,45 & 434,05 & 428,20 & 424,89 & 403,74 \\
\hline 1000 Угорських форинтів & 16 & 88,93 & 85,98 & 82,14 & 82,59 & 80,93 & 79,19 \\
\hline 100 Чеських крон & 17 & 113,22 & 108,89 & 105,45 & 106,58 & 105,59 & 102,75 \\
\hline 100 Шведських крон & 18 & 274,13 & 261,83 & 254,96 & 253,77 & 252,81 & 250,09 \\
\hline 100 Швейцарських франків & 19 & 2610,11 & 2575,86 & 2501,82 & 2496,83 & 2456,08 & 2398,30 \\
\hline 100 Юанів женьміньбі (Китай) & 20 & 374,52 & 358,51 & 348,00 & 349,19 & 347,14 & 336,31 \\
\hline 1000 Японських єн & 21 & 238,17 & 237,09 & 230,72 & 229,61 & 223,96 & 216,29 \\
\hline
\end{tabular}

Джерело : робота [33].

Основні статистичні оцінки курсів валют: середній за рік щомісячний курс $m$, його середнє квадра-

тичне відхилення $\sigma$ i коефіціснт варіації $\delta=\sigma / m$, приведено в табл. 2.

Таблиця 2

Основні статистичні характеристики курсів валют

\begin{tabular}{|c|c|c|c|c|c|c|c|c|}
\hline \multirow{2}{*}{ Показники } & \multicolumn{7}{|c|}{ Код валюти } \\
\cline { 2 - 9 } & 1 & 2 & 3 & 4 & 5 & 6 & 7 & 8 \\
\hline$m$ & 17,9861 & 32,9978 & 12,3502 & 3,87785 & 25,8456 & 28,9518 & 0,067561 & 19,4688 \\
\hline$\sigma$ & 1,21658 & 2,04475 & 0,500347 & 0,236059 & 1,29098 & 1,75622 & 0,004034 & 0,902301 \\
\hline$\delta, \%$ & $6,76 \%$ & $6,20 \%$ & $4,05 \%$ & $6,09 \%$ & $4,99 \%$ & $6,07 \%$ & $5,97 \%$ & $4,63 \%$ \\
\hline Код валюти & 9 & 10 & 11 & 12 & 13 & 14 & 15 & 16 \\
\hline$m$ & 1,47142 & 2,94313 & 6,73744 & 0,399102 & 35,7184 & 18,949 & 4,56344 & 0,089143 \\
\hline$\sigma$ & 0,084172 & 0,220211 & 0,417085 & 0,015874 & 1,97389 & 1,01484 & 0,358963 & 0,006897 \\
\hline$\delta, \%$ & $5,72 \%$ & $7,48 \%$ & $6,19 \%$ & $3,98 \%$ & $5,53 \%$ & $5,36 \%$ & $7,87 \%$ & $7,74 \%$ \\
\hline
\end{tabular}


Закінчення табл. 2

\begin{tabular}{|c|r|r|r|r|r|r|r|c|}
\hline Код валюти & \multicolumn{1}{|c|}{17} & \multicolumn{1}{c|}{18} & \multicolumn{1}{c|}{19} & \multicolumn{1}{c|}{20} & \multicolumn{1}{c|}{21} & - & - & - \\
\hline$m$ & 1,12772 & 2,73729 & 26,0025 & 3,74631 & 0,237035 & - & - & - \\
\hline$\sigma$ & 0,067859 & 0,193184 & 1,20866 & 0,258609 & 0,010628 & - & - & - \\
\hline$\delta, \%$ & $6,02 \%$ & $7,06 \%$ & $4,65 \%$ & $6,90 \%$ & $4,48 \%$ & - & - & - \\
\hline
\end{tabular}

Джерело: розроблено авторами.

Слід звернути увагу на те, що коефіцієнт варіації для всіх використаних для аналізу даних невеликий, що може свідчити про те, що окремі раптові коливання курсу мало впливають на його середнє значення.

Визначення статистичного зв'язку між окремими валютами, включеними до складу валютного портфеля. Для визначення міри взаємно- го статистичного зв'язку між змінами курсів валют, які вказані в табл. 1, побудована взаємна кореляційна матриця, що наведена в табл. 3. Для її обчислення використано коефіцієнт рангової кореляції Спірмена. Цей коефіцієнт використано тому, що він не накладає ніяких обмежень на закони розподілу вхідних даних.

Таблиця 3

Матриця взаємної кореляції курсів валют

\begin{tabular}{|c|c|c|c|c|c|c|c|c|c|c|c|}
\hline $\begin{array}{c}\text { Код } \\
\text { валюти }\end{array}$ & 1 & 2 & 3 & 4 & 5 & 6 & 7 & 8 & 9 & 10 & 11 \\
\hline \multirow{3}{*}{1} & & 0,9610 & $\begin{array}{ll}0,8781 \\
\end{array}$ & 0,9917 & 0,9873 & 0,9918 & 0,9948 & 0,9843 & 0,9617 & 0,9896 & 0,9892 \\
\hline & & (12) & (12) & (12) & (12) & (12) & (12) & (12) & (12) & (12) & (12) \\
\hline & & 0,0000 & 0,0002 & 0,0000 & 0,0000 & 0,0000 & 0,0000 & 0,0000 & 0,0000 & 0,0000 & 0,0000 \\
\hline \multirow{3}{*}{2} & 0,9610 & & 0,7660 & 0,9363 & 0,9269 & 0,9375 & 0,9518 & 0,9074 & 0,9356 & 0,9294 & 0,9453 \\
\hline & (12) & & (12) & (12) & (12) & (12) & (12) & (12) & (12) & (12) & (12) \\
\hline & 0,0000 & & 0,0037 & 0,0000 & 0,0000 & 0,0000 & 0,0000 & 0,0000 & 0,0000 & 0,0000 & 0,0000 \\
\hline \multirow{3}{*}{3} & 0,8781 & 0,7660 & & 0,9102 & 0,9256 & 0,9097 & 0,8951 & 0,9245 & 0,7807 & 0,9176 & 0,9088 \\
\hline & (12) & (12) & & (12) & (12) & (12) & (12) & (12) & (12) & (12) & (12) \\
\hline & 0,0002 & 0,0037 & & 0,0000 & 0,0000 & 0,0000 & 0,0001 & 0,0000 & 0,0027 & 0,0000 & 0,0000 \\
\hline \multirow{3}{*}{4} & 0,9917 & 0,9363 & 0,9102 & & 0,9965 & 1,0000 & 0,9962 & 0,9922 & 0,9539 & 0,9899 & 0,9941 \\
\hline & (12) & (12) & (12) & & (12) & (12) & (12) & (12) & (12) & (12) & (12) \\
\hline & 0,0000 & 0,0000 & 0,0000 & & 0,0000 & 0,0000 & 0,0000 & 0,0000 & 0,0000 & 0,0000 & 0,0000 \\
\hline \multirow{3}{*}{5} & 0,9873 & 0,9269 & 0,9256 & 0,9965 & & 0,9964 & 0,9951 & 0,9900 & 0,9431 & 0,9868 & 0,9868 \\
\hline & (12) & (12) & (12) & (12) & & (12) & (12) & (12) & (12) & (12) & (12) \\
\hline & 0,0000 & 0,0000 & 0,0000 & 0,0000 & & 0,0000 & 0,0000 & 0,0000 & 0,0000 & 0,0000 & 0,0000 \\
\hline \multirow{3}{*}{6} & 0,9918 & 0,9375 & 0,9097 & 1,0000 & 0,9964 & & 0,9962 & 0,9920 & 0,9538 & 0,9897 & 0,9947 \\
\hline & (12) & (12) & (12) & (12) & (12) & & (12) & (12) & (12) & (12) & (12) \\
\hline & 0,0000 & 0,0000 & 0,0000 & 0,0000 & 0,0000 & & 0,0000 & 0,0000 & 0,0000 & 0,0000 & 0,0000 \\
\hline \multirow{3}{*}{7} & 0,9948 & 0,9518 & 0,8951 & 0,9962 & 0,9951 & 0,9962 & & 0,9833 & 0,9514 & 0,9909 & 0,9893 \\
\hline & (12) & (12) & (12) & (12) & (12) & (12) & & (12) & (12) & (12) & (12) \\
\hline & 0,0000 & 0,0000 & 0,0001 & 0,0000 & 0,0000 & 0,0000 & & 0,0000 & 0,0000 & 0,0000 & 0,0000 \\
\hline \multirow{3}{*}{8} & 0,9843 & 0,9074 & 0,9245 & 0,9922 & 0,9900 & 0,9920 & 0,9833 & & 0,9473 & 0,9853 & 0,9850 \\
\hline & (12) & (12) & (12) & (12) & (12) & (12) & (12) & & (12) & (12) & (12) \\
\hline & 0,0000 & 0,0000 & 0,0000 & 0,0000 & 0,0000 & 0,0000 & 0,0000 & & 0,0000 & 0,0000 & 0,0000 \\
\hline \multirow{3}{*}{9} & 0,9617 & 0,9356 & 0,7807 & 0,9539 & 0,9431 & 0,9538 & 0,9514 & 0,9473 & & 0,9234 & 0,9390 \\
\hline & (12) & (12) & (12) & (12) & (12) & (12) & (12) & (12) & & (12) & (12) \\
\hline & 0,0000 & 0,0000 & 0,0027 & 0,0000 & 0,0000 & 0,0000 & 0,0000 & 0,0000 & & 0,0000 & 0,0000 \\
\hline \multirow{3}{*}{10} & 0,9896 & 0,9294 & 0,9176 & 0,9899 & 0,9868 & 0,9897 & 0,9909 & 0,9853 & 0,9234 & & 0,9893 \\
\hline & (12) & (12) & (12) & (12) & (12) & (12) & (12) & (12) & (12) & & (12) \\
\hline & 0,0000 & 0,0000 & 0,0000 & 0,0000 & 0,0000 & 0,0000 & 0,0000 & 0,0000 & 0,0000 & & 0,0000 \\
\hline \multirow{3}{*}{11} & 0,9892 & 0,9453 & 0,9088 & 0,9941 & 0,9868 & 0,9947 & 0,9893 & 0,9850 & 0,9390 & 0,9893 & \\
\hline & (12) & (12) & (12) & (12) & (12) & (12) & (12) & (12) & (12) & (12) & \\
\hline & 0,0000 & 0,0000 & 0,0000 & 0,0000 & 0,0000 & 0,0000 & 0,0000 & 0,0000 & 0,0000 & 0,0000 & \\
\hline \multirow{3}{*}{12} & 0,9482 & 0,9089 & 0,9244 & 0,9428 & 0,9419 & 0,9433 & 0,9458 & 0,9415 & 0,8407 & 0,9704 & 0,9612 \\
\hline & (12) & (12) & (12) & (12) & (12) & (12) & (12) & (12) & (12) & (12) & (12) \\
\hline & 0,0000 & 0,0000 & 0,0000 & 0,0000 & 0,0000 & 0,0000 & 0,0000 & 0,0000 & 0,0006 & 0,0000 & 0,0000 \\
\hline \multirow{3}{*}{13} & 0,9936 & 0,9439 & 0,9112 & 0,9989 & 0,9982 & 0,9989 & 0,9981 & 0,9900 & 0,9527 & 0,9901 & 0,9929 \\
\hline & (12) & (12) & (12) & (12) & (12) & (12) & (12) & (12) & (12) & (12) & (12) \\
\hline & 0,0000 & 0,0000 & 0,0000 & 0,0000 & 0,0000 & 0,0000 & 0,0000 & 0,0000 & 0,0000 & 0,0000 & 0,0000 \\
\hline
\end{tabular}


Продовження табл. 3

\begin{tabular}{|c|c|c|c|c|c|c|c|c|c|c|c|}
\hline \multirow{3}{*}{14} & 0,9974 & 0,9590 & 0,8978 & 0,9957 & 0,9925 & 0,9960 & 0,9956 & 0,9877 & 0,9573 & 0,9892 & 0,9947 \\
\hline & (12) & (12) & $(12)$ & (12) & (12) & (12) & (12) & (12) & (12) & (12) & (12) \\
\hline & 0,0000 & 0,0000 & 0,0001 & 0,0000 & 0,0000 & 0,0000 & 0,0000 & 0,0000 & 0,0000 & 0,0000 & 0,0000 \\
\hline \multirow{3}{*}{15} & 0,9128 & 0,8403 & 0,7661 & 0,9162 & 0,9011 & 0,9151 & 0,8994 & 0,9305 & 0,9650 & 0,8839 & 0,8910 \\
\hline & (12) & (12) & (12) & (12) & (12) & (12) & (12) & (12) & (12) & (12) & (12) \\
\hline & 0,0000 & 0,0006 & 0,0037 & 0,0000 & 0,0001 & 0,0000 & 0,0001 & 0,0000 & 0,0000 & 0,0001 & 0,0001 \\
\hline \multirow{3}{*}{16} & 0,9912 & 0,9471 & 0,8910 & 0,9955 & 0,9881 & 0,9953 & 0,9941 & 0,9852 & 0,9569 & 0,9896 & 0,9903 \\
\hline & (12) & (12) & (12) & (12) & (12) & (12) & (12) & (12) & (12) & (12) & (12) \\
\hline & 0,0000 & 0,0000 & 0,0001 & 0,0000 & 0,0000 & 0,0000 & 0,0000 & 0,0000 & 0,0000 & 0,0000 & 0,0000 \\
\hline \multirow{3}{*}{17} & 0,9915 & 0,9444 & 0,9037 & 0,9974 & 0,9900 & 0,9977 & 0,9921 & 0,9886 & 0,9521 & 0,9886 & 0,9987 \\
\hline & (12) & (12) & (12) & (12) & (12) & (12) & (12) & (12) & (12) & (12) & (12) \\
\hline & 0,0000 & 0,0000 & 0,0001 & 0,0000 & 0,0000 & 0,0000 & 0,0000 & 0,0000 & 0,0000 & 0,0000 & 0,0000 \\
\hline \multirow{3}{*}{18} & 0,9876 & 0,9437 & 0,8497 & 0,9860 & 0,9730 & 0,9863 & 0,9812 & 0,9747 & 0,9662 & 0,9754 & 0,9859 \\
\hline & (12) & (12) & (12) & (12) & (12) & (12) & (12) & (12) & (12) & (12) & (12) \\
\hline & 0,0000 & 0,0000 & 0,0005 & 0,0000 & 0,0000 & 0,0000 & 0,0000 & 0,0000 & 0,0000 & 0,0000 & 0,0000 \\
\hline \multirow{3}{*}{19} & 0,9645 & 0,8757 & 0,9215 & 0,9868 & 0,9830 & 0,9864 & 0,9719 & 0,9862 & 0,9343 & 0,9708 & 0,9762 \\
\hline & (12) & (12) & (12) & (12) & (12) & (12) & (12) & (12) & (12) & (12) & (12) \\
\hline & 0,0000 & 0,0002 & 0,0000 & 0,0000 & 0,0000 & 0,0000 & 0,0000 & 0,0000 & 0,0000 & 0,0000 & 0,0000 \\
\hline \multirow{3}{*}{20} & 0,9954 & 0,9646 & 0,8887 & 0,9878 & 0,9852 & 0,9879 & 0,9943 & 0,9755 & 0,9473 & 0,9901 & 0,9863 \\
\hline & (12) & (12) & (12) & (12) & (12) & (12) & (12) & (12) & (12) & (12) & (12) \\
\hline & 0,0000 & 0,0000 & 0,0001 & 0,0000 & 0,0000 & 0,0000 & 0,0000 & 0,0000 & 0,0000 & 0,0000 & 0,0000 \\
\hline \multirow{3}{*}{21} & 0,9182 & 0,7979 & 0,9413 & 0,9561 & 0,9613 & 0,9553 & 0,9365 & 0,9638 & 0,8788 & 0,9354 & 0,9373 \\
\hline & (12) & (12) & (12) & (12) & (12) & (12) & (12) & (12) & (12) & (12) & (12) \\
\hline & 0,0000 & 0,0019 & 0,0000 & 0,0000 & 0,0000 & 0,0000 & 0,0000 & 0,0000 & 0,0002 & 0,0000 & 0,0000 \\
\hline
\end{tabular}

\begin{tabular}{|c|r|r|r|r|r|r|r|r|r|r|}
\hline \multicolumn{1}{c}{ Код } \\
валюти
\end{tabular}


Закінчення табл. 3

\begin{tabular}{|c|c|c|c|c|c|c|c|c|c|c|}
\hline & & & & & & & & & & \\
\hline \multirow{3}{*}{11} & 0,9612 & 0,9929 & 0,9947 & \begin{tabular}{l|l}
0,8910 \\
\end{tabular} & 0,9903 & 0,9987 & 0,9859 & 0,9762 & 0,9863 & 0,9373 \\
\hline & (12) & (12) & (12) & (12) & (12) & (12) & (12) & (12) & (12) & (12) \\
\hline & 0,0000 & 0,0000 & 0,0000 & 0,0001 & 0,0000 & 0,0000 & 0,0000 & 0,0000 & 0,0000 & 0,0000 \\
\hline \multirow{3}{*}{12} & & 0,9471 & 0,9539 & 0,7822 & 0,9452 & 0,9499 & 0,9155 & 0,9074 & 0,9602 & 0,8693 \\
\hline & & (12) & (12) & (12) & (12) & (12) & (12) & (12) & (12) & (12) \\
\hline & & 0,0000 & 0,0000 & 0,0026 & 0,0000 & 0,0000 & 0,0000 & 0,0000 & 0,0000 & 0,0002 \\
\hline \multirow{3}{*}{13} & 0,9471 & & 0,9975 & 0,9074 & 0,9941 & 0,9956 & 0,9824 & 0,9809 & 0,9915 & 0,9495 \\
\hline & (12) & & (12) & (12) & (12) & (12) & (12) & (12) & (12) & (12) \\
\hline & 0,0000 & & 0,0000 & 0,0000 & 0,0000 & 0,0000 & 0,0000 & 0,0000 & 0,0000 & 0,0000 \\
\hline \multirow{3}{*}{14} & 0,9539 & 0,9975 & & 0,9081 & 0,9931 & 0,9961 & 0,9854 & 0,9717 & 0,9944 & 0,9308 \\
\hline & (12) & (12) & & (12) & (12) & (12) & (12) & (12) & (12) & (12) \\
\hline & 0,0000 & 0,0000 & & 0,0000 & 0,0000 & 0,0000 & 0,0000 & 0,0000 & 0,0000 & 0,0000 \\
\hline \multirow{3}{*}{15} & 0,7822 & 0,9074 & 0,9081 & & 0,9199 & 0,9101 & 0,9270 & 0,9249 & 0,8897 & 0,8854 \\
\hline & (12) & (12) & (12) & & (12) & (12) & (12) & (12) & (12) & (12) \\
\hline & 0,0026 & 0,0000 & 0,0000 & & 0,0000 & 0,0000 & 0,0000 & 0,0000 & 0,0001 & 0,0001 \\
\hline \multirow{3}{*}{16} & 0,9452 & 0,9941 & 0,9931 & 0,9199 & & 0,9941 & 0,9842 & 0,9763 & 0,9915 & 0,9341 \\
\hline & (12) & (12) & (12) & (12) & & (12) & (12) & (12) & (12) & (12) \\
\hline & 0,0000 & 0,0000 & 0,0000 & 0,0000 & & 0,0000 & 0,0000 & 0,0000 & 0,0000 & 0,0000 \\
\hline \multirow{3}{*}{17} & 0,9499 & 0,9956 & 0,9961 & 0,9101 & 0,9941 & & 0,9902 & 0,9822 & 0,9874 & 0,9438 \\
\hline & (12) & (12) & (12) & (12) & (12) & & (12) & (12) & (12) & (12) \\
\hline & 0,0000 & 0,0000 & 0,0000 & 0,0000 & 0,0000 & & 0,0000 & 0,0000 & 0,0000 & 0,0000 \\
\hline \multirow{3}{*}{18} & 0,9155 & 0,9824 & 0,9854 & 0,9270 & 0,9842 & 0,9902 & & 0,9742 & 0,9753 & 0,9223 \\
\hline & (12) & (12) & (12) & (12) & (12) & (12) & & (12) & (12) & (12) \\
\hline & 0,0000 & 0,0000 & 0,0000 & 0,0000 & 0,0000 & 0,0000 & & 0,0000 & 0,0000 & 0,0000 \\
\hline \multirow{3}{*}{19} & 0,9074 & 0,9809 & 0,9717 & 0,9249 & 0,9763 & 0,9822 & 0,9742 & & 0,9542 & 0,9832 \\
\hline & (12) & (12) & (12) & (12) & (12) & (12) & (12) & & (12) & (12) \\
\hline & 0,0000 & 0,0000 & 0,0000 & 0,0000 & 0,0000 & 0,0000 & 0,0000 & & 0,0000 & 0,0000 \\
\hline \multirow{3}{*}{20} & 0,9602 & 0,9915 & 0,9944 & 0,8897 & 0,9915 & 0,9874 & 0,9753 & 0,9542 & & 0,9065 \\
\hline & (12) & (12) & (12) & (12) & (12) & (12) & (12) & (12) & & (12) \\
\hline & 0,0000 & 0,0000 & 0,0000 & 0,0001 & 0,0000 & 0,0000 & 0,0000 & 0,0000 & & 0,0000 \\
\hline \multirow{3}{*}{21} & 0,8693 & 0,9495 & 0,9308 & 0,8854 & 0,9341 & 0,9438 & 0,9223 & 0,9832 & 0,9065 & \\
\hline & (12) & (12) & (12) & (12) & (12) & (12) & (12) & (12) & (12) & \\
\hline & 0,0002 & 0,0000 & 0,0000 & 0,0001 & 0,0000 & 0,0000 & 0,0000 & 0,0000 &, 0000 & \\
\hline
\end{tabular}

Джерело: розроблено авторами.

У кожній комірці табл. 3 дані розташовані в наступному порядку: у першому рядку приведено чисельне значення оцінки коефіціснта рангової кореляції, у другому рядку вказана кількість спостережень, відповідна даним, наведеним у табл. 1, у третьому рядку наведено значення величини $\Pi \mathrm{v}$, що оцінюе якість отриманої оцінки. Оскільки у всіх випадках величина $\Pi v<0,05$, то отримані оцінки слід вважати значущими. Величина $\Pi v=0,0000$ означає, що в цьому випадку $\Pi v<1 \cdot 10^{-4}$. Високий рівень взаємної кореляції між курсами валют, наведеними в табл. 1, говорить про рівень глобалізації світової економіки, де зміна вартості однієї валюти приводить до реакції інших і навпаки. Чим сильніша економічна і політична інтеграція держав, тим сильніше взаємна кореляція курсів валют.

Визначення статистичних властивостей часового ряду даних про зміни курсу валют. При розміщенні КВ на депозитних рахунках на тривалий час виникає потреба в прогнозуванні ії курсу відносно НВ. Незалежно від того або іншого методу прогнозування необхідне вивчення статистичних влас- тивостей тимчасового ряду, утвореного даними про курс КВ відносно НВ. Зважаючи на показану в табл. 3 високу взаємну кореляцію між курсами КВ відносно НВ далі розглянемо зміну щоденного курсу долара США щодо гривні в 2018 і 2019 рp. [33]. Ці зміни показано на рис. 1, рис. 2.

Time Sequence Plot

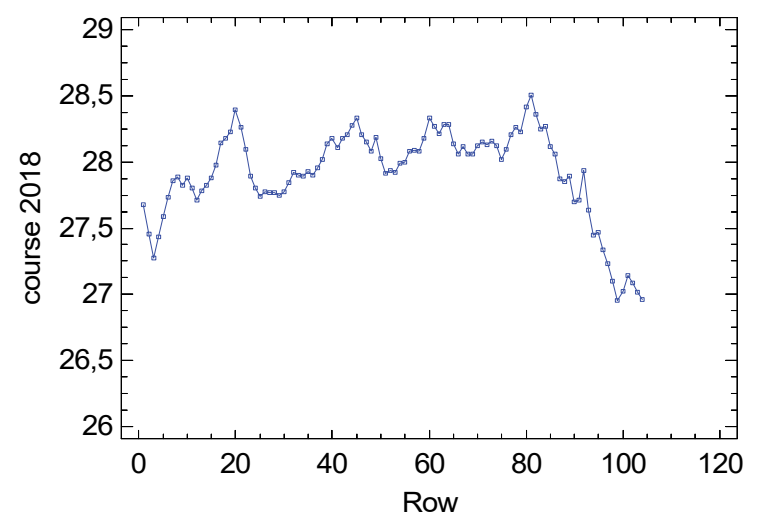

Рис. 1. Зміна курсу долара США щодо гривні у 2018 р. Джерело: розроблено авторами. 
Time Sequence Plot

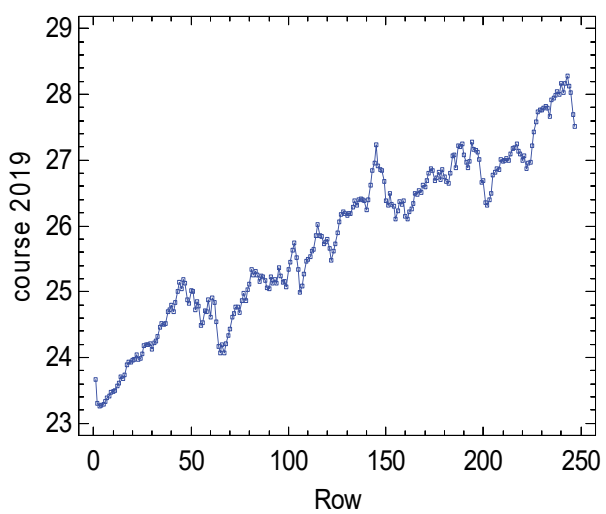

Рис. 2. Зміна курсу долара США щодо гривні у 2019 р. Джерело: розроблено авторами.

3 цих рисунків виходить, що це нестаціонарні процеси, що мають чітко виражений, але різний тренд. Для визначення пам'яті процесу були обчислені автокореляційні функції цих процесів, графіки яких показано на рис. 3 і рис. 4. Обчислення виконано 3 використанням програмної системи STATGRAPHICS V.15.

Estimated Autocorrelations for course 2018

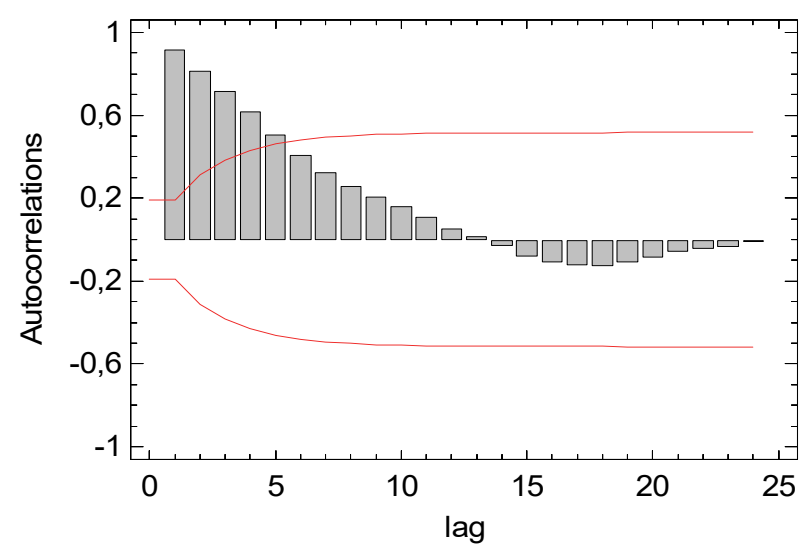

Рис. 3. Графік автокореляційної функції зміни курсу долара США щодо гривні у 2018 р.

Джерело: розроблено авторами.
Estimated Autocorrelations for course 2019

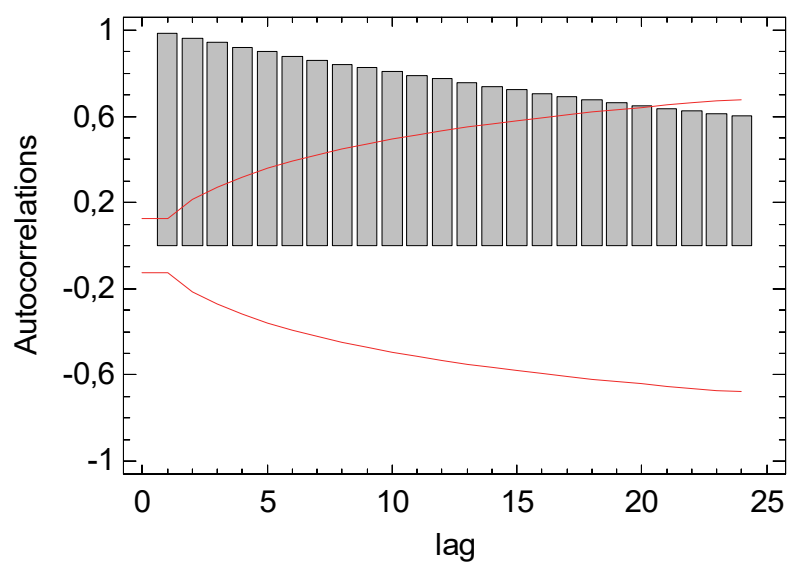

Рис. 4. Графік автокореляційної функції зміни курсу долара США щодо гривні у 2019 р.

Джерело: розроблено авторами.

На цих графіках вище за лінії обмеження розташовані ті коефіцієнти, які істотно відрізняються від нуля. Їх чисельні значення приведені у табл. 4. У цій таблиці прийнято наступні умовні позначення: КАР - чисельне значення коефіцієнта автокореляції, СКП - його середня квадратична помилка; жирним шрифтом виділені значення коефіцієнтів, статистична достовірність яких встановлена.

3 даних цієї таблиці виходить, що розглянуті процеси мають різну глибину пам'яті (5 і 20 кроків відповідно). Можливі причини цього в рамках даної роботи не розглянуто. У табл. 5 приведено результати перевірки гіпотези про відсутність тренду в рядах даних, графіки яких показано на рис. 1 і рис. 2.

Теоретичне обгрунтування цих критеріїв надано в роботі [25]. Оскільки для всіх використаних тестів велична $\Pi v<1 \cdot 10^{-4}$, то 3 рівнем достовірності 0,95 гіпотеза про випадковість значень цього ряду може бути відхилена. Проведений аналіз дозволяє зробити висновок про те, що процес зміни курсу валют - нестаціонарний процес, прогнозування якого вимагає побудови спеціальних економетричних моделей.

Таблиця 4

Чисельні значення автокореляційної функції курсу долара щодо гривні

\begin{tabular}{|r|r|r|r|r|r|r|r|r|r|}
\hline \multirow{2}{*}{ Лаг } & \multicolumn{2}{|c|}{$2018 \mathrm{p}}$. & \multicolumn{2}{c|}{$2019 \mathrm{p}}$. & \multicolumn{2}{c|}{ Лаг } & \multicolumn{2}{c|}{$2018 \mathrm{p}}$. & \multicolumn{2}{c|}{$2019 \mathrm{p}}$. \\
\cline { 2 - 10 } & \multicolumn{1}{|c|}{ КАР } & \multicolumn{1}{c|}{ СКП } & \multicolumn{1}{c|}{ КАР } & \multicolumn{1}{c|}{ СКП } & & \multicolumn{1}{c|}{ КАР } & \multicolumn{1}{c|}{ CКП } & \multicolumn{1}{c}{ КАР } & \multicolumn{1}{c|}{ СКП } \\
\hline 1 & $\mathbf{0 , 9 1 6 2 6 4}$ & 0,0980581 & $\mathbf{0 , 9 8 4 7 3 6}$ & 0,0636285 & 13 & 0,0157085 & 0,261802 & $\mathbf{0 , 7 5 5 5 8 5}$ & 0,280901 \\
\hline 2 & $\mathbf{0 , 8 1 1 6 9}$ & 0,1605 & $\mathbf{0 , 9 6 5 4 0}$ & 0,109089 & 14 & 0,033531 & 0,261811 & $\mathbf{0 , 7 3 9 8 4 9}$ & 0,289012 \\
\hline 3 & $\mathbf{0 , 7 1 7 5 3}$ & 0,196037 & $\mathbf{0 , 9 4 3 6 7}$ & 0,139453 & 15 & 0,082119 & 0,261853 & $\mathbf{0 , 7 2 3 9 4 3}$ & 0,296581 \\
\hline 4 & $\mathbf{0 , 6 1 5 8 3}$ & 0,219844 & $\mathbf{0 , 9 2 1 9 7}$ & 0,163272 & 16 & 0,110473 & 0,2621 & $\mathbf{0 , 7 0 7 6 8 8}$ & 0,303651 \\
\hline 5 & $\mathbf{0 , 5 0 5 9 4}$ & 0,235849 & $\mathbf{0 , 9 0 0 3 7}$ & 0,183141 & 17 & 0,127262 & 0,262548 & $\mathbf{0 , 6 9 2 8 9 1}$ & 0,310256 \\
\hline 6 & 0,40494 & 0,246064 & $\mathbf{0 , 8 7 9 9 5}$ & 0,200262 & 18 & 0,131411 & 0,26314 & $\mathbf{0 , 6 7 8 7 8}$ & 0,316459 \\
\hline 7 & 0,3234 & 0,252391 & $\mathbf{0 , 8 6 2 0 8}$ & 0,215348 & 19 & $-0,11421$ & 0,26377 & $\mathbf{0 , 6 6 4 7 9 6}$ & 0,3223 \\
\hline 8 & 0,25843 & 0,256344 & $\mathbf{0 , 8 4 3 5 0}$ & 0,228894 & 20 & $-0,08822$ & 0,264245 & $\mathbf{0 , 6 5 1 1 6 4}$ & 0,327804 \\
\hline 9 & 0,203656 & 0,258837 & $\mathbf{0 , 8 2 6 3 4 8}$ & 0,24115 & 21 & $-0,05884$ & 0,264528 & 0,638004 & 0,333 \\
\hline 10 & 0,15816 & 0,260374 & $\mathbf{0 , 8 0 9 1 1}$ & 0,252354 & 22 & $-0,04627$ & 0,264654 & 0,625954 & 0,337913 \\
\hline 11 & 0,10522 & 0,261296 & $\mathbf{0 , 7 9 1 5 6}$ & 0,262647 & 23 & $-0,03647$ & 0,264732 & 0,614068 & 0,342575 \\
\hline 12 & 0,05204 & 0,261703 & $\mathbf{0 , 7 7 3 7 8}$ & 0,272134 & 24 & $-0,01441$ & 0,26478 & 0,603463 & 0,347003 \\
\hline
\end{tabular}

Джерело: розроблено авторами. 
Перевірка гіпотези про відсутність тренду в зміні курсу долара США по відношенню до гривні

\begin{tabular}{|l|c|c|c|c|r|r|}
\hline \multirow{2}{*}{$\begin{array}{c}\text { Характеристики } \\
\text { критерію }\end{array}$} & \multicolumn{4}{|c|}{ Тип критерію } \\
\cline { 2 - 7 } & \multicolumn{2}{|c|}{ Критерій медіан } & \multicolumn{1}{|c|}{ Критерій серій } & \multicolumn{2}{|c|}{ Критерій Бокса-Пирса } \\
\hline Роки & 2018 р. & 2019 p. & 2018 р. & 2019 р. & 2018 p. & 2019 р. \\
\hline Чисельні значення критерію & 8,96692 & 15,2693 & 4,57056 & 8,60826 & 327,169 & 3639,52 \\
\hline Значущість критерію, Пv & $<1 \cdot 10^{-4}$ & $<1 \cdot 10-4$ & $<1 \cdot 10^{-4}$ & $<1 \cdot 10^{-4}$ & $<1 \cdot 10^{-4}$ & $<1 \cdot 10^{-4}$ \\
\hline
\end{tabular}

Джерело: розроблено авторами.

Тому для розв'язання задачі про формування портфеля валют доцільно використовувати спеціальні методи прогнозування, одним з яких може бути метод інтервального аналізу.

У даній роботі всі підготовчі розрахунки, які необхідні для досягнення поставленої мети дослідження, виконано з використанням спеціалізованого програмного калькулятора, який наведено в роботі [26]. Для подальшої роботи необхідно виконати визначення можливих у майбутньому меж інтервалів, що містять параметри процесу зміни курсу валют. Один $з$ таких методів, заснований на апараті нечіткої логіки і призначений для прогнозування курсу валют, описано в роботі [27]. Запропонований у даній роботі метод інтервалів можна розглядати як варіант методу нечіткої логіки з постійним значенням функції приналежності. Межі інтервалів у цьому випадку можна визначити, використовуючи прогнозні методи експертних оцінок, які описано в роботах [28-29]. Докладніший розгляд цих методів виходить за рамки даної роботи. Теоретичні основи нелінійної оптимізації при інтервально визначених коефіцієнтах цільової функції викладено в роботі [30]. Спосіб чисельної реалізації цього методу описано в роботі [31]. Розглянемо детально цей спосіб.

Множину $A=\{\xi\}$ дійсних чисел $\xi$, які задовольняють умові $a_{1} \leq \xi \leq a_{2}$ називають інтервальним числом:

$$
[A]=\left[a_{1}, a_{2}\right] \text {, }
$$

де $a_{1}<a_{2}$. Якщо $a_{1}=a_{2}$, то число $A$ називають виродженим інтервальним числом.

Інтервальним числом, визначеним у системі ЦЕНТР-РАДІУС, називають число $A=\left\langle a, r_{a}\right\rangle$. Зв'язок між цими визначеннями видно з умови:

$$
[A]=\left[a-r_{a}, a+r_{a}\right] .
$$

Різниця між цими визначеннями виявляється в особливостях виконання дій над інтервальними числами. Порівняння цих способів визначення інтерва-

льних чисел виконано в роботі [32]. Розв'язання нелінійної задачі оптимізації детально розглянуто в роботах [34-35]. У відповідності з роботами [30-31; 34 35] припустимо, що відома довільна, в загальному випадку нелінійна, неперервна функція $z$ змінних

$$
D(X)=F\left(x_{1}, \ldots, x_{z}\right)
$$

в області

$$
\Phi_{g}\left(x_{1}, \ldots, x_{z}\right) \leq b_{g} ; g=1, \ldots, t .
$$

У виразах (15) і (16) значення усіх змінних та параметрів, що входять в ці функції, представлено виродженими інтервальними числами. Тоді задача умовної оптимізації може бути сформульована як класична задача нелінійного програмування:

$$
\begin{gathered}
L=F\left(x_{1}, \ldots x_{u .} \ldots, x_{z}\right) \rightarrow \max ; \Phi_{g}\left(x_{1}, \ldots, x_{u}, \ldots, x_{z}\right) \leq b_{g} ; \\
x_{u} \geq 0 .
\end{gathered}
$$

У разі використання інтервальних чисел, що визначені співвідношеннями (13)-(14), функції (15)(16) представляють у вигляді їх інтервальних розширень, виконаних по методиці, яка викладена в роботі [32]. Позначимо інтервальне розширення довільної функції $D(X)$ символом $\tilde{D}(X)$. Тоді, враховуючи (13), отримаємо інтервально визначену функцію:

$$
\tilde{D}(X)=\left[D_{1}(X), D_{2}(X)\right] .
$$

Методи, які використовують для розв'язання задач оптимізації функцій з інтервальними змінними і параметрами, можна згрупувати в дві групи. До першої групи входять методи, що вимагають спеціального математичного забезпечення. Ці методи описано, наприклад, у роботах [29; 35]. До другої групи входять роботи [31;35], в яких розв'язання задачі інтервальної оптимізації зводять до розв'язання задач оптимізації традиційними методами. В цьому випадку розглядають дві задачі, які автор вказаних робіт назвав верхньою і нижньою задачею оптимізації. Особливості визначення цих здач показано у табл. 6.

Таблиця 6 Редукція задачі нелінійної оптимізації в умовах нестохастичної невизначеності до класичної задачі оптимізації

\begin{tabular}{|c|c|}
\hline \multicolumn{2}{|c|}{ Тип задачі оптимізації } \\
\hline Нижня гранична задача & Верхня гранична задача \\
\hline$L_{1}=F_{1}\left(x_{1}, \ldots x_{u}, \ldots, x_{z}\right) \rightarrow \max$ & $L_{2}=F_{2}\left(x_{1}, \ldots x_{u}, \ldots, x_{z}\right) \rightarrow \max$ \\
\hline$\Phi_{g 1}\left(x_{1}, \ldots x_{u}, \ldots, x_{z}\right) \leq b_{g 1}, x_{u} \geq 0, g=1, \ldots, t$. & $\Phi_{g 1}\left(x_{1}, \ldots x_{u}, \ldots, x_{z}\right) \leq b_{g 1}, x_{u} \geq 0, g=1, \ldots, t$ \\
\hline$\Phi_{g 2}\left(x_{1}, \ldots x_{u}, \ldots, x_{z}\right) \leq b_{g 2}, x_{u} \geq 0, g=1, \ldots, t$. & $\Phi_{g 2}\left(x_{1}, \ldots x_{u}, \ldots, x_{z}\right) \leq b_{g 2}, x_{u} \geq 0, g=1, \ldots, t$ \\
\hline
\end{tabular}

Джерело: розроблено авторами. 
Розв'язком нижньої граничної задачі буде величина $F_{1}$ max. Розв'язком верхньої граничної задачі буде величина $F_{2}$ max. Тоді інтервальне число, яке буде розв'язком задачі, дорівнює:

$$
\tilde{F}_{\max }=\left[F_{1} \max , F_{2} \max \right] .
$$

Методи другої групи дають ширший інтервал розв'язку ніж методи першої групи. У роботі [31], використовуючи введені в роботі [36] методи порівняння інтервалів, показано, що для визначення центру інтервалу, який містить розв'язок, необхідно розв'язати наступну задачу оптимізації:

$$
\begin{gathered}
F_{1}\left(x_{1}, \ldots x_{u}, \ldots, x_{z}\right)+F_{2}\left(x_{1}, \ldots x_{u}, \ldots, x_{z}\right) \rightarrow \max ;(20) \\
\Phi_{g 1}\left(x_{1}, \ldots x_{u}, \ldots, x_{z}\right)+\Phi_{g 2}\left(x_{1}, \ldots x_{u}, \ldots, x_{z}\right) \leq b_{g 1}+b_{g 2} ; \\
x_{u} \geq 0 ; g=1, \ldots, t .
\end{gathered}
$$

Методи визначення центрів інтервального розширення умов (20)-(21) детально розглянуто в роботах $[24 ; 26 ; 32]$. Автори даної роботи, керуючись правилом, яке наведено в роботі [37]: “Нема чобіт, узувай постоли”, обрали методи другої групи.

Розв'язання задачі векторної оптимізації 3 використанням інтервальних чисел, які представлені в системі ЦЕНТР-РАДІУС. Відповідно до умов задачі Марковіца, визначених виразами (5)(11) для формування валютного портфеля необхідно визначити міру його ефективності. Використовуючи вирази (3) і (4), ефективність валютної операції, яку виконано згідно зі схемою $\mathrm{HB} \rightarrow \mathrm{KB} \rightarrow \mathrm{KB} \rightarrow \mathrm{HB}$ по відношенню до операції, виконаної за схемою $\mathrm{HB} \rightarrow \mathrm{HB}$ визначимо виразом:

$$
E=\frac{S_{n}^{(2)}}{S_{n}^{(1)}}-1=\frac{1+n j}{(1+n i) K_{0}} \cdot K_{1}-1 .
$$

3 умов задачі виходить, що величини $i, j, n, K_{0}$ заздалегідь визначено умовами договору і їх слід вважати виродженими інтервальними числами.
Величину $K_{1}$ визначимо як інтервальне число вигляду $\left[K_{1}\right]=\left[k_{1}, k_{2}\right]$. Подібне припущення обумовлене тим, що курс КВ по відношенню НВ, який діятиме через $n$ років, можна визначити тільки приблизно. Спосіб визначення цього курсу в даній роботі не розглядається. Інтервальну величину ефективності валютної операції визначимо відповідно до роботи [32] виразом:

$$
[E]=C\left[K_{1}\right]-1=\left[e_{1}, e_{2}\right]=\left\langle\frac{e_{1}+e_{2}}{2} ; \frac{e_{2}-e_{1}}{2}\right\rangle,
$$

де

$$
C=\frac{1+n j}{(1+i n) K_{0}} .
$$

Для визначення загального ризику операції величини $W$ необхідно, як це витікає з виразу (6), знання попарної коваріації між валютами, які включено до валютного портфелю. Інтервальний аналіз не дає можливості визначити величину коваріації, проте методи, які викладено в роботі [37], дозволяють це зробити при певних припущеннях. Для цього слід використовувати екстремальні властивості ентропії, які приведено в роботі [38]:

- на обмеженому відрізку значень випадкової величини максимальна ентропія буде при рівномірному розподілі;

- ентропія неперервної випадкової величини при одному й тому ж середньому квадратичному відхиленні буде найбільшою у тому випадку, коли закон розподілу випадкової величини буде нормальним.

Далі, замість інтервальної величини $[E]=\left[e_{1}\right.$, $e_{2}$, яку визначено виразом (23), розглядатимемо рівномірно розподілену випадкову величину $E$, властивості якої моделюють інтервальну величину $[E]$. Ïї основні числові характеристики взято 3 роботи [39] і наведено в табл. 7.

Основні числові характеристики рівномірного розподілу, що моделює інтервальну величину

\begin{tabular}{|c|c|c|c|}
\hline \multirow{2}{*}{$\begin{array}{c}\text { Щільність } \\
\text { розподілу }\end{array}$} & \multicolumn{2}{|c|}{ Основні числові характеристики розподілу } \\
\cline { 2 - 4 } & $\begin{array}{c}\text { Математичне } \\
\text { сподівання }\end{array}$ & $\begin{array}{c}\text { Середньоквадратичне } \\
\text { відхилення }\end{array}$ & $\begin{array}{c}\text { Коефіцієнт } \\
\text { варіації }\end{array}$ \\
\hline Рівномірний розподіл & $m_{u}=\frac{e_{1}+e_{2}}{2}$ & $\sigma_{u}=\frac{e_{2}-e_{1}}{2 \sqrt{3}}$ & $e_{2}-e_{1}$ \\
$\left(e_{2}+e_{1}\right) \sqrt{3}$
\end{tabular}

Джерело: розроблено авторами.

У цій таблиці й далі прийнято, що нижній індекс $u$ позначає рівномірний розподіл, нижній індекс $n$ позначає нормальний розподіл. Використовуючи правило “трьох сигм” отримаємо, що:

$$
\sigma_{n}=\frac{e_{2}-e_{1}}{6}=\frac{\sigma_{u}}{\sqrt{3}}
$$

У роботі [39, С. 179] показано, що для симетричних розподілів наближеною оцінкою математичного сподівання може бути величина $m_{u}$, яку наве- дено в табл. 7. У цьому випадку наближеним значенням коефіцієнта варіації може бути величина:

$$
\delta_{n}=\frac{e_{2}-e_{1}}{3\left(e_{2}+e_{1}\right)}=\frac{\delta_{u}}{\sqrt{3}} .
$$

Вирази (25)-(26) і табл. 7 надають можливість визначити значення основних числових характеристик умовного нормального розподілу як функції рівномірного розподілу, точніше, як функції меж інтервалу можливої зміни курсу КВ. 
Беручи до уваги вирази (18); (23)-(24) і табл. 7 оцінка ефективності валютної операції з портфелем валют для нижньої і верхньої межі можливої зміни значень набуває виразів:

$$
\begin{gathered}
L_{1}=\sum_{u=1}^{z} x_{u 1}\left(C_{u} K_{u 1}-1\right)=\sum_{u=1}^{z} x_{u 1} e_{u 1} ; \\
L_{2}=\sum_{u=1}^{z} x_{u 2}\left(C_{u} K_{u 2}-1\right)=\sum_{u=1}^{z} x_{u 2} e_{u 2} .
\end{gathered}
$$

У роботі [42, С. 240] для меж коефіцієнта варіації $\delta_{n}$ нормально розподіленої випадкової величини отримана наступна нерівність:

$$
\frac{\delta_{n}}{1+\mu \sqrt{1+2 \delta_{n}^{2}}}<\delta<\frac{\delta_{n}}{1-\mu \sqrt{1+2 \delta_{n}^{2}}},
$$

де

$$
\mu=\frac{z}{\sqrt{2(n-1)}} \text {. }
$$

У цьому виразі прийнято, що $z-$ квантиль нормального розподілу, в нашому випадку $z=1,96$, що відповідає двосторонній довірчій вірогідності $a=0,975, n-$ кількість даних. Підставляючи вираз (25) в (29) отримаємо для $u$-ї валюти нижнє $\delta_{n u 1} \mathrm{i}$ верхнє $\delta_{n и 2}$ значення коефіцієнтів варіації умовного нормального розподілу:

$$
\begin{aligned}
& \delta_{n 1 u}=\frac{\delta_{u u}}{\sqrt{3}-\mu \sqrt{2 \delta_{u u}^{2}+3}} ; \\
& \delta_{n 2 u}=\frac{\delta_{u u}}{\sqrt{3}+\mu \sqrt{2 \delta_{u u}^{2}+3}} .
\end{aligned}
$$

Вирази (26); (31) і (32) надають можливість виразити значення коефіцієнта варіації умовного нормального розподілу як функцію ширини інтервалу можливої зміни значень курсу валюти.

Для виконання подальших обчислень необхідно визначити нижню і верхню межу інтервалу можливих значень коефіцієнта кореляції між курсами валют, який наведено в табл. 3. Для цього, відповідно до роботи [43], необхідно обчислити величини:

$$
\begin{aligned}
& z_{1}=\frac{1}{2} \ln \frac{1+r}{1-r}-\frac{1,96}{\sqrt{n-3}}-\frac{r}{2(n-1)} ; \\
& z_{2}=\frac{1}{2} \ln \frac{1+r}{1-r}+\frac{1,96}{\sqrt{n-3}}-\frac{r}{2(n-1)},
\end{aligned}
$$

де $r$ - обчислене значення коефіцієнта кореляції.

Тоді отримаємо вираз коефіцієнта кореляції у вигляді інтервального числа:

$$
R=\left[\operatorname{th}\left(z_{1}\right) ; \operatorname{th}\left(z_{2}\right)\right]=\left[r_{1} ; r_{2}\right] .
$$

Для інтервального обчислення величини сумарного ризику валютної операції з урахуванням виразів (6)-(7) і роботи [44, С. 212] введемо наступні позначення:

$$
\begin{gathered}
H_{u 1}^{2}=x_{u 1}^{2}\left(\delta_{n 1 u} m_{u}\right)^{2}, H_{u 2}^{2}=x_{u 2}^{2}\left(\delta_{n 2 u} m_{u}\right)^{2} \\
D_{u q 1}=x_{u 1} x_{q 1} \cdot\left(\delta_{n 1 u} m_{u}\right) \cdot\left(\delta_{n 1 q} m_{u}\right), \\
D_{u q 2}=x_{u 2} x_{q 2} \cdot\left(\delta_{n 2 u} m_{u}\right) \cdot\left(\delta_{n 2 q} m_{u}\right) .
\end{gathered}
$$

У цьому випадку нижне і верхне значення інтервального ризику буде дорівнювати:

$$
\begin{aligned}
& W_{1}=\sqrt{\sum_{u=1}^{z} H_{u 1}^{2}+2 \sum_{u<q} t h\left(z_{1}\right)_{u q} D_{u q 1}} ; \\
& W_{2}=\sqrt{\sum_{u=1}^{z} H_{u 2}^{2}+2 \sum_{u<q} t h\left(z_{2}\right)_{u q} D_{u q 2}} .
\end{aligned}
$$

Вирази (27)-(38) надають можливість представити однокритеріальну пряму і обернену задачі Марковіца в інтервальному вигляді, наведеному в табл. 8.

Умови однокритеріальної прямої і оберненої задачі Марковіца

Таблиця 8 Варіанти з прямої і оберненої задачі Марковіца ${ }^{*}$

\begin{tabular}{|l|l|l|l|}
\hline \multicolumn{4}{|c|}{ Варіанти з прямої і оберненої задачі Марковіца } \\
\hline \multicolumn{2}{|c|}{ Пряма задача } & \multicolumn{2}{c|}{ Обернена задача } \\
\hline \multicolumn{1}{|c|}{ Нижня задача } & \multicolumn{1}{|c|}{ Верхня задача } & \multicolumn{1}{c|}{ Нижня задача } & \multicolumn{1}{c|}{ Верхня задача } \\
\hline$L_{1} \rightarrow \max$ & $L_{2} \rightarrow \max$ & $W_{1} \rightarrow \min$ & $W_{2} \rightarrow \min$ \\
\hline$W_{1} \leq W_{01}$ & $W_{1} \leq W_{01}$ & $L_{1} \geq L_{1 o}$ & $L_{1} \geq L_{1 o}$ \\
\hline$W_{2} \leq W_{02}$ & $W_{2} \leq W_{02}$ & $L_{2}$ & $L_{20}$ \\
\hline$\sum_{u=1}^{z} x_{u 1}=1, e_{u 1} \geq 0$ & $\sum_{u=1}^{z} x_{u 2}=1, e_{u 2} \geq 0$ & $\sum_{u=1}^{z} x_{u 1}=1, e_{u 1} \geq 0$ & $\sum_{u=1}^{z} x_{u 2}=1, e_{u 2} \geq 0$ \\
\hline
\end{tabular}

*) Для обчислення величин $L_{1}, L_{2}, W_{1}, W_{2}$ слід використати вирази (27)-(28); (38).

Джерело: розроблено авторами.

Для отримання відповідних співвідношень для двохкритеріальної задачі Марковіца в інтервальному вигляді:

$$
\tilde{L}=\sum_{u=1}^{z} x_{u} \tilde{e}_{u} \rightarrow \max
$$

$$
\begin{gathered}
\tilde{W}=\sqrt{\sum_{u=1}^{z} \tilde{H}_{u}^{2}+2 \sum_{u<q} \operatorname{th}(\tilde{z})_{u q} D_{u q} \rightarrow \min } ; \\
\sum_{u=1}^{z} x_{u}=1 ; x_{u} \geq 0 ; u=1, \ldots, z .
\end{gathered}
$$


Визначимо нижню та верхню задачі оптимізації (27)-(28); (38):

$$
\begin{gathered}
L_{1} \rightarrow \max ; W_{1} \rightarrow \min ; \sum_{u=1}^{z} x_{u}=1 ; \\
x_{u} \geq 0 ; u=1, \ldots, z . \\
L_{2} \rightarrow \max ; W_{2} \rightarrow \min ; \sum_{u=1}^{z} x_{u}=1 ; \\
x_{u} \geq 0 ; u=1, \ldots, z .
\end{gathered}
$$

Зведемо їх до однокритеріальних задач згідно 3 методом згортки, який викладено в роботі [45]:

$$
U_{1}=\max \left\{\frac{L_{1 \max }-L_{1}}{L_{1 \max }}, \frac{W_{1}-W_{1 \min }}{W_{1 \min }}\right\},
$$

$$
U_{2}=\max \left\{\frac{L_{2 \max }-L_{2}}{L_{2 \max }}, \frac{W_{2}-W_{2 \min }}{W_{2 \min }}\right\},
$$

де $L_{\text {imax }}, W_{\text {imin }} ; i=1,2$ - оптимальні значення цільових функцій для однокритеріальних задач:

$$
\sum_{u=1}^{z} x_{u}=1, x_{u} \geq 0, u=1, \ldots, z, \quad i=1,2 .
$$

та

$$
W_{i} \rightarrow \min ; \sum_{u=1}^{z} x_{u}=1, x_{u} \geq 0, u=1, \ldots, z, \quad i=1,2 .
$$

Ці згортки забезпечують зменшення відносних значень цільових функцій від їх оптимальних значень рівномірно. Співвідношення для розв'язання двохкритеріальної задачі Марковіца в інтервальному вигляді наведені в табл. 9.

Таблиця 9

Співвідношення для розв'язання двохкритеріальної задачі Марковіца в інтервальному вигляді

\begin{tabular}{|l|l|}
\hline \multicolumn{2}{|c|}{ Двохпараметрична задача Марковіца в інтервальному виді } \\
\hline \multicolumn{1}{|c|}{ Нижня задача } & \multicolumn{1}{c|}{ Верхня задача } \\
\hline$U_{1} \rightarrow \min$ & $U_{2} \rightarrow \min$ \\
\hline$\sum_{u=1}^{z} x_{u}=1 ; \sum_{u=1}^{z} x_{u}=1, x_{u} \geq 0 ; u=1, \ldots, z$. & $\sum_{u=1}^{z} x_{u}=1 ; \sum_{u=1}^{z} x_{u}=1, x_{u} \geq 0 ; u=1, \ldots, z$. \\
\hline
\end{tabular}

Джерело: розроблено авторами.

Таким чином запропонована методика надає можливість визначати структуру портфеля валют як наслідок розв'язання однокритеріальної та двохкритеріальної задачі Марковица.

\section{Висновки}

1. На основі аналізу літератури встановлено, що невизначеності різної природи, які властиві операціям по конвертації валют з урахуванням чинника часу, вимагають використовувати хеджування валютних ризиків.

2. Встановлено, що серед моделей хеджування ризиків одна 3 найбільш поширених моделей - модель Марковіца. В роботі розглянуто іiї використання за результатами можливих значень курсу валют у майбутньому.

3. Для розв'язання задачі у майбутньому часі запропоновано використання інтервальних чисел, представлених в системі ЦЕНТР-РАДІУС.
4. В роботі запропоновано наступні методики: визначення основних статистичних характеристик зміни курсів валют, включених до складу портфелю; визначення статистичного зв'язку між окремими валютами, включеними до складу портфелю; визначення статистичних властивостей часового ряду даних про зміну курсу валют.

5. Сформульовано задачу Марковіца як задачу багатокритеріальної (векторної) оптимізації портфеля валют при нестохастично невизначеному зовнішньому економічному середовищі. Розв'язання такої задачі (структура портфелю валют) одночасно дає можливість максимізувати прибуток і одночасно мінімізувати ризик операцій, пов'язаних з конверсією валют.

6. Для розв'язання задачі використано згортку критеріїв, яка забезпечує зменшення відносних значень цільових функцій від їх оптимальних значень рівномірно.

\section{Список літератури}

1. Руководство по платежному балансу и международной инвестиционной позиции. Вашингтон, округ Колумбия: Международный валютный фонд, 2012. 440 с.

2. Дзюблюк О. В. Валютна політика. Тернопіль : ТДЕУ, 2006. 91 с.

3. Бурковська А. В., Лункіна Т. І. Міжнародні кредитно-розрахункові та валютні операції в сучасних умовах. Миколаїв : МНАУ, 2012. 247 с.

4. Міжнародні фінанси / Мозговий О. М. та ін.; за наук. ред. д. е. н., проф. О. М. Мозгового. Київ : КНЕУ, 2015. $515 \mathrm{c}$.

5. Лебідь О. В. Міжнародні розрахунки і валютні операції. Харків : ХНЕУ ім. С. Кузнеця, 2016. 200 с.

6. Григорків В. С., Ярошенко О. І., Нікіфоров П. О. Фінансова математика. Чернівці : ЧНУ, 2011. 488 с.

7. Заболоцький М. В., Прокопишин І. А. Основи фінансової математики. Львів : ЛНУ ім. Івана Франка, 2016.144 с.

8. Долінський Л. Б.Фінансова математика. Київ : КНЕУ, 2009. 265 с. 
9. Голіченко I. І., Клесов О. І. Фінансова математика та елементи актуарної математики. Київ : КПІ ім. Ігоря Сікорського, 2019. $104 \mathrm{c}$.

10. Жуленев С. В. Финансовая математика: введение в классическую теорию. Москва : Издательство МГУ, 2001. $480 \mathrm{c}$.

11. Четыркин Е. М. Финансовая математика. Москва : Дело, 2000. 400 с.

12. Козловський С. В., Козловський В. О. Макроекономічне моделювання та прогнозування валютного курсу в Україні : монографія. Вінниця: “Книга - Вега”, 2005. 240 с.

13. Яременко О. Ф., Матвієць О. В. Фінансові операції з іноземною валютою: математичний підхід. Науковий вісник Ужгородського начіонального університету, Серія: Міжнародні економічні відносини та світове господарство, 2019. Вип. 25. Частина 2. С. 171-175.

14. Положення про встановлення офіційного курсу гривні до іноземних валют та розрахунку довідкового значення курсу гривні до долара США й облікової ціни банківських металів : Постанова Правління Національного банку України 10.12.2019 № 148 .

15. Олейник Д. А. Экономико-математическая модель валютного курса к резервной валюте. Экономика Украины. 2015. Вип. 11(640). С. 56-70.

16. Дубницкий В. Ю., Кобылин А. М., Шкодина И. В. Финансово-аналитический программный калькулятор для выполнения валютных расчётов в условиях стохастически неопределённой внешней экономической среды. Системи обробки інформаиії. 2016. № 1(138). С. 107-112.

17. Вербіцька І. І. Хеджування валютних ризиків. Сталий розвиток економіки. 2013. № 4’2013 [21]. С. 374-380.

18. Люу Ю. Д. Методы и алгоритмы финансовой математики. Москва : БИНОМ. Лаборатория знаний, 2014. 754 с.

19. Шарп У., Алесандер Г., Бэйли Дж. Инвестиции. Москва : ИНФРА-М, 2001. 1028 с.

20. Дубницький В. Ю, Самородов Б. В. Одночасне розв'язання прямої і зворотної задачі Марковіца пошуковим методом. Системи обробки інформації. 2010. № 8(89). С. 126-130.

21. Федосеев А. А. Решение трехкритериальной и четырехкритериальной моделей Марковица. Известия Тульского государственного университета, Естественные науки. 2014. Вып. 3. С. 197-207.

22. Мурга Н. А. Нечеткий фондовый портфель. Исследование и оптимизация. Системні дослідження та інформаиійні технології. 2010. № 3. С. 60-71.

23. Добряк В. С., Мазорчук М. С., Бакуменко Н. С. Моделирование структуры портфеля проектов в условиях неопределённости. Радіоелектронні і комп 'ютерні системи. 2008. № 4(31). С. 101-105.

24. Дубницкий В. Ю., Кобылин А. М., Кобылин О. А. Вычисление значений элементарных функций с интервально заданным аргументом в системе центр-радиус. Системи обробки інформащії. 2016. № 7(144). С. 107-112.

25. Кобзарь А. И. Прикладная математическая статистика. Для инженеров и научных работников. Москва: ФИЗМАТЛИТ, 2006. $816 \mathrm{c}$.

26. Дубницкий В. Ю., Кобылин А. М., Кобылин О. А. Вычисление значений элементарных и специальных функций с интервально заданным аргументом, определённым в системе ЦЕНТР - РАДИУС. Прикладная радиоэлектроника. 2017. № 3, 4. Том 16. С. 147-154.

27. Козловський С. В., Козловський В. О. Макроекономічне моделювання та прогнозування валютного курсу в Україні : монографія. Вінниця : “Книга - Вега”, 2005. 240 с.

28. Давнис В. В., Тинякова В. И. Прогнозные модели экспертных предпочтений : монография. Воронеж : Издательство Воронежского государственного университета, 2005. 248 с.

29. Мандель С. А. Метод аналогов в прогнозировании коротких временных рядов : экспертно-статистический подход. Автоматика и телемеханика. 2004. № 4. С. 143-152.

30. Ащепков Т. А., Косогорова И. Б. Минимизация квадратичной функции с интервальными коэффициентами. Журнал вычислительной математики и математической физики. 2002. Том 42. Вып. 5. С. 653-664.

31. Левин В. И. Упрощённая методика оптимизации систем в условиях интервальной неопределённости. Информационные технологии. 2012. № 12(196). С. 19-24.

32. Жуковська О. А. Основи інтервального аналізу. Київ : Освіта України, 2009. 136 с.

33. Офіційний 1 курс $\quad$ гривні 1 щодо 1 іноемних https://bank.gov.ua/ua/markets/exchangerates?date=03.05.2021\&period=daily (дата звертання 13.03.2021).

34. Левин В. И. Интервальный подход к оптимизации в условиях неопределенности. Системы управления связи и безопасности. 2015. № 4. С. 123-135.

35. Вощинин А. П., Сотиров Г. Р. Оптимизация в условиях неопределенности. София : Издательство “Техника”, 1989. $224 \mathrm{c}$.

36. Левин В. И. Сравнение интервальных чисел и оптимизация систем с интервальными параметрами. Автоматика и телемеханика. 2004. № 4. С. 133-142.

37. Олійник I. С., Сидоренко М. М. Українсько-російський і російсько-український фразеологічний тлумачний словник. Київ : Радянська школа, 1991. 400 с.

38. Кузнецов В. П. Интервальные статистические модели. Москва : Радио и связь, 1991. 352 с.

39. Лившиц Н. А., Пугачев В. Н. Вероятностный анализ систем автоматического управления. В 2 т. Т.1 : Вероятностные и статистические характеристики воздействий и процессов. Линейные стационарные и нестационарные системы. Москва : Советское радио, 1963. 896 с.

40. Вадзинский Р. Н. Справочник по статистическим распределениям. Санкт-Петербург : Наука, 2001. 295 с.

41. Дэйвид Г. Порядковые статистики. Москва : Наука, 1979. 336 с.

42. Закс Л. Статистическое оценивание. Москва : Статистика, 1976. 598 с.

43. Айвазян С. А. Статистическое исследование зависимостей. Москва : Металлургия, 1968. 227 с.

44. Венцель Е. С., Овчаров Л. А. Теория вероятностей. Москва : Наука, 1969. 368 с.

45. Гадецька С. В., Дубницький В. Ю., Кушнерук Ю. І., Філатова Л. Д., Черепньов І. А. Багатокритеріальна (векторна) оптимізація раціону військовослужбовців, розташованих в стаціонарних і польових умовах. Системи озброєння $i$ військова техніка. 2019. № 2(58). С. 152-167. https://doi.org/10.30748/soivt.2019.58.18. 


\section{References}

1. International Monetary Fund (2012), "Rukovodstvo po platezhnomu balansu i mezhdunarodnoj investicionnoj pozicii" [A Guide to Balance of Payments and International Investment Position], Washington, DC, $440 \mathrm{p}$.

2. Dziubliuk, O.V. (2006), "Valiutna polityka" [Monetary policy], TDEU, Ternopil, 91 p.

3. Burkovska, A.V. and Lunkina, T.I.(2012), "Mizhnarodni kredytno-rozrakhunkovi ta valiutni operatsii v suchasnykh umovakh" [International credit and settlement and currency transactions in modern conditions], MNAU, Mykolaiv, $247 \mathrm{p}$.

4. Mozghovyi, O. M. (2015), "Mizhnarodni finansy" [International Finance], KNEU, Kyiv, 515 p.

5. Lebid, O. V. (2016), "Mizhnarodni rozrakhunky i valiutni operatsii" [International calculations and currency transactions], S. Kuznets KhNEU, Kharkiv, 200 p.

6. Grigorkiv, V.S., Yaroshenko, O.I. and Nikiforov, P.O. (2011), "Finansova matematyka" [Financial mathematics], ChNU, Chernivtsi, $488 \mathrm{p}$.

7. Zabolotskiy, M.V. and Prokopishin, I.A. (2016), "Osnovy finansovoi matematyky" [Fundamentals of financial mathematics], Ivan Franko LNU, Lviv, 144 p.

8. Dolinskyi, L.B. (2009), "Finansova matematyka" [Financial Mathematics], KNEU, Kyiv, 265 p.

9. Holichenko, I.I. and Klesov, O.I. (2019), "Finansova matematyka ta elementy aktuarnoi matematyky" [Financial mathematics and elements of actuarial mathematics], Igor Sikorsky KPI, Kyiv, 104 p.

10. Zhulenev, S.V. (2001), "Finansovaja matematika: vvedenie v klassicheskuju teoriju" [Financial mathematics: an introduction to classical theory], Moscow State University Publishing House, Moscow, $480 \mathrm{p}$.

11. Chetyrkin, E.M. (2000), "Finansovaja matematika" [Financial mathematics], Delo, Moscow, 400 p.

12. Kozlovsky, S.V. and Kozlovsky, V.O. (2005), "Makroekonomichne modeliuvannia ta prohnozuvannia valiutnoho kursu v Ukraini: monohrafia" [Macroeconomic modeling and forecasting of the exchange rate in Ukraine: a monograph], "Knyha - Veha", Vinnytsia, 240 p.

13. Yaremenko, O. F. and Matviiets, O. V. (2019), "Finansovi operatsii z inozemnoiu valiutoiu: matematychnyi pidkhid" [Financial transactions with foreign currency: a mathematical approach], Scientific Bulletin of Uzhhorod National University, Series: International Economic Relations and the World Economy, Issue 25, Part 2, pp. 171-175.

14. The Board of the National Bank of Ukraine (2019), "Polozhennia pro vstanovlennia ofitsiinoho kursu hryvni do inozemnykh valiut ta rozrakhunku dovidkovoho znachennia kursu hryvni do dolara SShA y oblikovoi tsiny bankivskykh metaliv vid 10.12.2019 No. 148" [Regulations on establishing the official exchange rate of hryvnia to foreign currencies and calculating the reference value of the hryvnia exchange rate against the US dollar and the book price of bank metals dated 12.10.2019 No. 148].

15. Olejnik D.A. (2015), "Jekonomiko-matematicheskaja model' valjutnogo kursa k rezervnoj valjute" [Economicmathematical model of the exchange rate to the reserve currency], Economy of Ukraine, Issue 11(640), pp. 56-70.

16. Dubnytskyi, V.Yu., Kobylin, A.M. and Shkodyna, Y.V. (2016), "Fynansovo-analytycheskyi prohrammnyi kalkuliator dlia vypolnenyia valiutnykh raschotov v uslovyiakh stokhastychesky neopredelonnoi vneshnei ekonomycheskoi sredy" [Financial analytical calculator for currency calculations under stochastically indeterminate ambient economic environment], Information Processing Systems, No. 1(138), pp. 107-112

17. Verbitska, I.I. (2013), "Khedzhuvannia valiutnykh ryzykiv" [Currency risk hedging], Sustainable economic development, No. 4’2013 [21], pp. 374-380.

18. Lyuu, Yu.D. (2014), "Metody i algoritmy finansovoy matematiki" [Methods and algorithms of financial mathematics], BINOM. Knowledge Laboratory, Moscow, $754 \mathrm{p}$

19. Sharpe, W., Alesander, G. and Bailey, J (2001), "Investicii" [Investments], INFRA-M, Moscow, 1028 p.

20. Dubnytskyi, V.Yu. and Samorodov, B.V. (2010), "Odnochasne rozviazannia priamoi i zvorotnoi zadachi Markovitsa poshukovym metodom" [Simultaneous decision of direct and reverse Markovits task method by searching], Information Processing Systems, № 8(89), pp. 126-130.

21. Fedoseev, A.A. (2014), "Resheniye trekhkriterial'noy i chetyrekhkriterial'noy modeley Markovitsa" [Solution of threecriteria and four-criteria Markowitz models], Bulletin of the Tula State University, Natural Sciences, Issue 3, pp. 197-207.

22. Murga, N.A. (2010), "Nechetkyy fondovyy portfel'. Yssledovanye i optymyzatsyya" [Fuzzy stock portfolio. Research and optimization], Systemni doslidzhennya ta informatsiyni tekhnolohiyi, No. 3. pp. 60-71

23. Dobryak, V.S., Mazorchuk, M.S. and Bakumenko, N.S. (2008), "Modelyrovanye struktury portfelia proektov v uslovyiakh neopredelennosty" [Modeling of project portfolio structure under conditions of uncertainty], Electronic and Computer Systems, No. 4(31), pp. 101-105.

24. Dubnitskiy, V.Yu., Kobylin, A.M. and Kobylin, O.A. (2016), "Vychislenie znachenij jelementarnyh funkcij s interval'no zadannym argumentom v sisteme centr-radius" [Calculation of elementary function values with interval stated argument determined in center-radius system], Information Processing Systems, No. 7(126), pp. 107-112.

25. Kobzar, A.I. (2006), "Prikladnaya matematicheskaya statistika. Dlya inzhenerov i nauchnykh rabotnikov" [Applied Mathematical Statistics. For engineers and scientific workers], FIZMATLIT, Moscow, 816 p.

26. Dubnitskiy, V.Yu., Kobylin, A.M. and Kobylin, O.A. (2017), "Vychisleniye znacheniy elementarnykh i spetsial'nykh funktsiy s interval'no zadannym argumentom, opredelonnym v sisteme CENTR - RADIUS" [Derivation of the similarity indicators and numerical integration of the similarity criterions, which are interval-based in system center-radius], Applied Radio Electronics, No. 3,4, Vol. 16, pp. 147-154.

27. Kozlovsky, S.V. and Kozlovsky, V.O. (2005), "Makroekonomichne modeliuvannia ta prohnozuvannia valiutnoho kursu $v$ Ukraini : monohrafiia" [Macroeconomic model and forecasting of the exchange rate in Ukraine: monograph], "Knyha Veha", Vinnytsia, $240 \mathrm{p}$.

28. Davnis, V.V. and Tinyakova, V.I. (2005), "Prognoznyye modeli ekspertnykh predpochteniy: monografiya" [Predictive models of expert preferences: monograph], Voronezh State University Publishing House, Voronezh, $248 \mathrm{p}$.

29. Mandel, S.A. (2004), "Metod analogov v prognozirovanii korotkikh vremennykh ryadov: ekspertno-statisticheskiy 
podkhod" [Method of analogues in forecasting short time series: expert-statistical approach], Automation and telemechanics, No. 4, pp.143-152.

30. Ashchepkov, T.A. and Kosogorova, I.B. (2002), "Minimizatsiya kvadratichnoy funktsii s interval'nymi koeffitsiyentami" [Minimization of a quadratic function with interval coefficients], Journal of Computational Mathematics and Mathematical Physics, No. 5, Vol. 42, pp. 653-664.

31. Levin, V.I. (2012), “Uproshhjonnaja metodika optimizacii sistem v uslovijah interval'noj neopredeljonnosti” [Simplified method of optimization of systems in conditions of interval uncertainty], Information Technology, No. 12(196), pp. 19-24. $136 \mathrm{p}$.

32. Zhukovska, O.A. (2009), "Osnovy intervalnoho analizu" [Fundamentals of interval analysis], Osvita Ukrainy, Kyiv,

33. "Ofitsiinyi kurs hryvni shchodo inozemnykh valiut" [The official exchange rate of hryvnia against foreign currencies], available at: https://bank.gov.ua/ua/markets/exchangerates?date=03.05.2021\&period=daily (accessed 13.03.2021).

34. Levin, V.I. (2015), "Interval'nyy podkhod k optimizatsii v usloviyakh neopredelennosti" [Interval approach to optimization in conditions of uncertainty], Communication and security control systems, No. 4, pp. 123-135.

35. Voshchinin, A.P. and Sotirov, G.R. (1989), "Optimizacija v uslovijah neopredelennosti” [Optimization under uncertainty], Tekhnika Publishing House, Sofia, 224 p.

36. Levin, V.I. (2004), "Sravneniye interval'nykh chisel i optimizatsiya sistem s interval'nymi parametrami” [Comparison of interval numbers and optimization of systems with interval parameters], Automation and Telemechanics, No. 4, pp. 133-142.

37. Oliinyk, I.S. and Sydorenko, M.M. (1991), "Ukrainsko-rosiiskyi i rosiisko-ukrainskyi frazeolohichnyi tlumachnyi slovnyk" [Ukrainian-Russian and Russian-Ukrainian phrase logical dictionary], Kyiv, 400 p.

38. Kuznecov, V.P. (1991). "Interval'nye statisticheskie modeli" [Interval statistical models], Radio i svjaz', Moscow, $352 \mathrm{p}$.

39. Livshic, N.A. and Pugachev, V.N. (1963), "Verojatnostnyj analiz sistem avtomaticheskogo upravlenija V 2 t. T.1: Verojatnostnye i statisticheskie harakteristiki vozdejstvij i processov. Linejnye stacionarnye i nestacionarnye sistemy" [Probabilistic analysis of automatic control systems. In 2 vol. Vol. 1: Probabilistic and statistical characteristics of influences and processes. Linear stationary and non-stationary systems], Soviet radio, Moscow, 896 p.

40. Vadzinsky, R.N. (2001), "Spravochnik po statisticheskim raspredelenijam" [Handbook of Statistical Distributions], Nauka, St. Petersburg, 295 p.

41. Deyvid, G. (1979), "Porjadkovye statistiki” [Ordinal statistics], Nauka, Moscow, 336 p.

42. Zaks, L. (1976), "Statisticheskoe ocenivanie" [Statistical estimation], Statistika, Moscow, 598 p.

43. Ajvazjan, S.A. (1968), "Statisticheskoe issledovanie zavisimostej" [Statistical Study of Dependencies], Metallurgy Publishing House, Moscow, 227 p.

44. Ventsel, E.S. and Ovchrov, L.A. (1969), “Teorija verojatnostej” [Probability theory], Nauka, Moscow, 368 p.

45. Hadetska, S.V., Dubnytskyi, V.Yu., Kushneruk, Yu.I., Filatova, L.D. and Cherepnov, I.A. (2019), "Bahatokryterialna (vektorna) optymizatsiia ratsionu viiskovosluzhbovtsiv, roztashovanykh v statsionarnykh i polovykh umovakh" [Multi-criteria (vector) optmization of military rations under presidial and field conditions], Systems of Arms and Military Equipment, No. 2(58), pp. 152-167. https://doi.org/10.30748/soivt.2019.58.18.

Надійшла до редколегії 02.08.2021 Схвалена до друку 14.09.2021

\section{Відомості про авторів:}

\section{Гадецька Світлана Вікторівна}

кандидат фізико-математичних наук доцент

доцент Харківського національного автомобільно-дорожнього університету, Харків, Україна

https://orcid.org/0000-0002-9125-2363

\section{Дубницький Валерій Юрійович}

кандидат технічних наук

старший науковий співробітник

старший науковий співробітник

навчально-наукового інституту “Каразінський

банківський інститут” Харківського національного університету ім. В.Н. Каразіна,

Харків, Україна

https://orcid.org/0000-0003-1924-4104

\section{Кушнерук Юрій Іонович}

кандидат технічних наук доцент

доцент Харківського національного університету

Повітряних Сил ім. І. Кожедуба,

Харків, Україна

https://orcid.org/0000-0001-5844-7137

\section{Information about the authors:}

\section{Svitlana Gadetska}

PhD in Physics and Mathematics Associate Professor

Senior Lecturer of Kharkiv National

Automobile and Highway University,

Kharkiv, Ukraine

https://orcid.org/0000-0002-9125-2363

\section{Valeriy Dubnitskiy}

Candidate of Technical Sciences

Senior Research

Senior Research Associate

of "Karazin Banking Institute"

of V.N. Karazin Kharkiv

National University,

Kharkiv, Ukraine

https://orcid.org/0000-0003-1924-4104

\section{Youriy Kushneruk}

Candidate of Technical Sciences Associate Professor

Senior Lecturer of Ivan Kozhedub

Kharkiv National Air Force University,

Kharkiv, Ukraine

https://orcid.org/0000-0001-5844-7137 
Ходирсв Олександр Іванович

старший викладач навчально-наукового інституту

“Каразінський банківський інститут” Харківського національного університету ім. В.Н. Каразіна,

Харків, Україна

https://orcid.org/0000-0001-9871-9440

\section{Шкодіна Ірина Віталіївна}

доктор економічних наук професор

навчально-наукового інституту

“Каразінський банківський інститут” Харківського національного університету ім. В.Н. Каразіна,

Харків, Україна

https://orcid.org/0000-0003-4035-3188
Alexander Khodyrev

Senior Instructor of "Karazin Banking Institute"

of V.N. Karazin Kharkiv

National University,

Kharkiv, Ukraine

https://orcid.org/0000-0001-9871-9440

Irina Shkodina

Doctor of Economic Sciences Professor

of "Karazin Banking Institute"

of V.N. Karazin Kharkiv

National University,

Kharkiv, Ukraine

https://orcid.org/0000-0003-4035-3188

\title{
МНОГОКРИТЕРИАЛЬНАЯ (ВЕКТОРНАЯ) ОПТИМИЗАЦИЯ ПОРТФЕЛЯ ВАЛЮТ ПРИ НЕСТОХАСТИЧЕСКИ НЕОПРЕДЕЛЕННОЙ ВНЕШНЕЙ ЭКОНОМИЧЕСКОЙ СРЕДЕ
}

\author{
С.В. Гадецкая, В.Ю. Дубницкий, Ю.И. Кушнерук, А.И. Ходирев, И.В. Шкодина
}

На основе анализа литературы установлено, что неопределенности различной природы (стохастические и нестохастические), присущче операциям по конвертации валют с учетом фактора времени, требуют хеджирования валютных рисков. Установлено, что среди моделей хеджсирования рисков одна из наиболее распространенных моделей - модель Марковица (задача Марковица). Для решения этой задачи в будущем времени предложено использование интервальных чисел, представленных в системе ЦЕНТР-РАДИУС. В работе предложены следующие методики: определение основных статистических характеристик изменения курсов валют, включенных в состав портфеля; определение статистической связи между отдельными валютами, включенными в состав портфеля; определение статистических свойств временного ряда данных об изменении курса валют. Сформулирована задача Марковица как задача многокритериальной (векторной) оптимизачии портфеля валют при нестохастически неопределенной внешней экономической среде. Решение такой задачи (определение структуры портфеля валют) одновременно дает возможность максимизировать прибыль и одновременно минимизировать риск операций, связанных с конвертацией валют. Для решения задачи использована свёртка критериев, которая обеспечивает равномерное уменьшение относительных значений иелевых функиий.

Ключевые слова: валютные операции, конвертация валюты, хеджирования рисков, задача Марковица, векторная оптимизация, интервальные вычисления.

\section{CURRENCY PORTFOLIO MULTI-CRITERION (VECTORED) OPTIMIZATION UNDER NON-STOCHASTICALLY UNCERTAIN ECONOMIC ENVIRONMENT}

S. Gadetska, V. Dubnitskiy, Y. Kushneruk, A. Khodyrev, I. Shkodina

On the basis of literature analysis it was found that uncertainties of various natures inherent in currency conversion operations considering time factor require currency risk hedging. The following options were analyzed for currency deposition: national currency - national currency, converted currency - converted currency, converted currency - national currency - national currency - converted currency, national currency - converted currency-converted currency - national currency. Currency portfolio formation efficiency assessment was studied for national currency - converted currency - converted currency - national currency option as compared to national currency - national currency option. Interval value was proposed for currency operation efficiency assessment. One of the most widely used among risk hedging models was found to be Markowitz model. In the work its application was studied by results of currency exchange rate probable values assessment. It was advised to apply interval value comparison theory which brings said comparison to comparison of like borders of those intervals. Analysis of solution methods for problems with interval variables and parameters showed that these methods are reduced to those requiring special mathematical support and those leading to problem solution by traditional methods. Solution of Markowitz interval problem was reduced to solution of two conditional optimization determinate problems in the form of corresponding top and bottom problems which permits application of well-known determinate function optimization methods. In solution of conditional optimization interval problem interval numbers were used as represented in CENTER-RADIUS system. The work proposed such methodologies: determination of basic statistical characteristics of portfolio-forming currencies exchange rate variation; statistical connection finding among particular portfolio forming currencies; determination of statistical properties of currencies exchange rate variation temporal data series.

Markowitz problem was formulated as problem of currency portfolio multi-criterion (vectored) optimization under nonstochastically uncertain economic environment. Solution of such a problem (currency portfolio structure) will at the same time enable profit maximization and currency risk minimization in connection with currency conversion. To solve the two-criterion optimization problem a convolution of criteria is proposed which ensures uniform reduction of target function relative values from their optimal values for respective one-criterion optimization problems.

Keywords: currency operations, currency conversion, risk hedging, Markowitz problems, vectored optimization, interval calculation. 